DOE/OR/20722-7

(DE84015853)

Surplus Facilities Management Program (SFMP)

Contract No. DE-AC05-810R20722

\title{
RADIOLOGICAL SURVEY REPORT FOR THE WELDON SPRING RAFFINATE PITS SITE
} Weldon Spring, Missouri
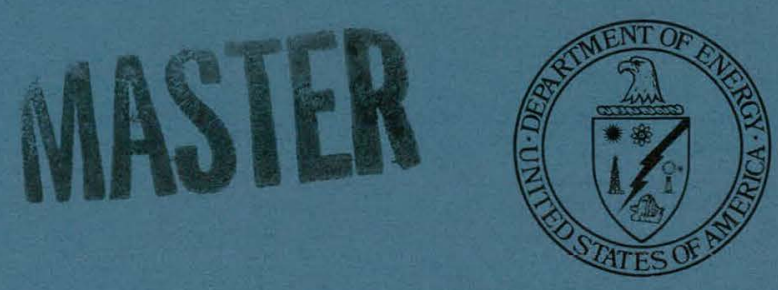

Technical Information Center

Office of Scientific and Technical Information 


\section{DISCLAIMER}

This report was prepared as an account of work sponsored by an agency of the United States Government. Neither the United States Government nor any agency Thereof, nor any of their employees, makes any warranty, express or implied, or assumes any legal liability or responsibility for the accuracy, completeness, or usefulness of any information, apparatus, product, or process disclosed, or represents that its use would not infringe privately owned rights. Reference herein to any specific commercial product, process, or service by trade name, trademark, manufacturer, or otherwise does not necessarily constitute or imply its endorsement, recommendation, or favoring by the United States Government or any agency thereof. The views and opinions of authors expressed herein do not necessarily state or reflect those of the United States Government or any agency thereof. 


\section{DISCLAIMER}

Portions of this document may be illegible in electronic image products. Images are produced from the best available original document. 


\title{
DISCLAIMER
}

\begin{abstract}
This report was prepared as an account of work sponsored by an agency of the United States Government. Neither the United States Government nor any agency thereof, nor any of their employees, makes any warranty, express or implied, or assumes any legal liability or responsibility for the accuracy, completeness, or usefulness of any information, apparatus, product, or process disclosed, or represents that its use would not infringe privately owned rights. Reference herein to any specific commercial product, process, or service by trade name, trademark, manufacturer, or otherwise does not necessarily constitute or imply its endorsement, recommendation, or favoring by the United States Government or any agency thereof. The views and opinions of authors expressed herein do not necessarily state or reflect those of the United States Government or any agency thereof.
\end{abstract}

This report has been reproduced directly from the best available copy.

Available from the National Technical Information Service, U. S. Department of Commerce, Springfield, Virginia 22161.

Price: Printed Copy $\mathrm{A03}$

Microfiche A01

Codes are used for pricing all publications. The code is determined by the number of pages in the publication. Information pertaining to the pricing codes can be found in the current issues of the following publications, which are generally available in most libraries: Energy Research Abstracts (ERA); Government Reports Announcements and Index (GRA and I); Scientific and Technical Abstract Reports (STAR); and publication NTIS-PR-360 available from NTIS at the above address. 


\title{
RADIOLOGICAL SURVEY REPORT FOR THE \\ WELDON SPRING RAFFINATE PITS SITE
}

AUGUST 1984

\begin{abstract}
Prepared for
UNITED STATES DEPARTMENT OF ENERGY

OAK RIDGE OPERATIONS OFFICE

Under Contract No. DE-AC05-810R20722
\end{abstract}

By

Bechtel National, Inc.

Advanced Technology Division

Oak Ridge, 'T'ennessee

Bechtel Job No. 14501 


\section{THIS PAGE \\ WAS INTENTIONALLY \\ LEFT BLANK}


The Weldon Spring site (WSS) is a U.S. Department of Energy (DOE) surplus facility comprising the Raffinate Pits facility, the Quarry, and potentially contaminated vicinity properties. Radiological characterization of the WSS will be conducted in three phases: the Raffinate Pits facility, Quarry, and the vicinity properties. Bechtel National, Inc. (BNI) and its radiological support subcontractor, Eberline Instrument Corporation (EIC), conducted a radiological characterization survey of the Raffinate Pits during 1982 and 1983 in support of on-site construction work and a technical evaluation of site geology. The survey consisted of direct beta-gamma surface readings, near-surface gamma readings, exposure level measurements, and gamma-logs of boreholes. Soil samples were also collected from the surface, shallow boreholes, and trenches on the site.

This report describes the radiological characterization of the Raffinate Pits facility, the procedures used to conduct the survey, the survey results, and their significance. 


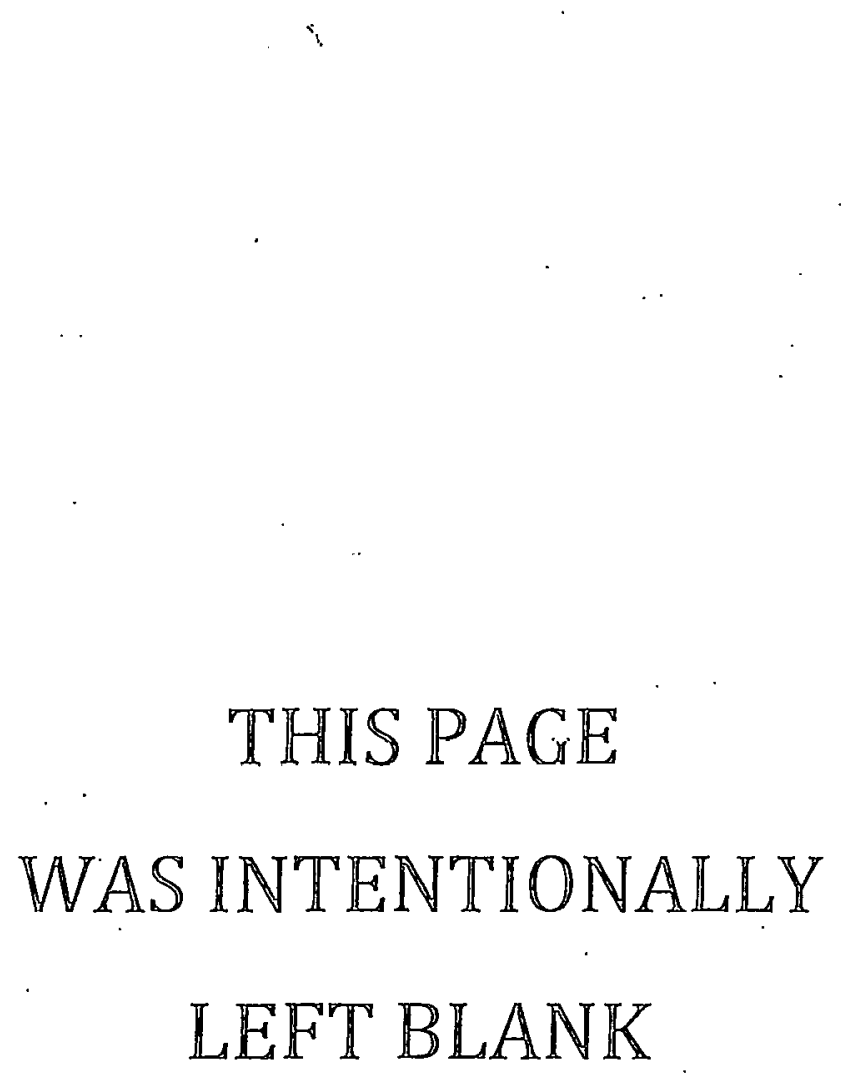


TABLE OF CONTENTS

$\underline{\text { Page }}$

1.0 Introduction

2.0 Site Background and Description

2.1 Summary of Site History

2.2 Description of the Raffinate Pits

3.0 Survey Procedures

10

3.1 Field Measurements

10

3.2 Sample Collection and Analysis

4.0 Survey Results

4.1. Direct Measurements

4.2 Sample Analysis

5.0 Summary and Significance of Findings

References 


\section{LIST OF FIGURES}

Figure

$1-1$

$1-2$

$1-3$

$4-1$

$4-2$

$4-3$

4-4

4-5

$4-6$
Title

Page

Weldon Spring Site (WSS) Area Map

2

WSS Vicinity Map

3

WSS Raffinate Pit Area

4

Results of Direct Gamma Measurements at the WSRP Site

Exposure Rates $(\mu R / h)$ at the WSRP Site

Location of Gamma-Logged Boreholes at the WSRP site

Location of Surface Soil samples at the WSRP Site

Location of Surface Soil Samples Exceeding

Uranium-238, Radium-226, and Thorium-232

Guidelines at the WSRP Site

Location of Trench Soil Samples at the WSRP Site 
Surface Area, Volume, and Contents of the Weldon Spring Raffinate Pits

Residual Contamination Guidelines for Formerly Utilized Sites and Remote Surplus Facilities Management Program Sites

Radionuclide Concentrations in Surface Soil Samples from the WSRP Site

Background Radiation Levels and Nuclide Concentrations in Surface Soil Samples in the state of Missouri 


\section{ABBREVIATIONS}

$\begin{array}{ll}\mathrm{Cm} & \text { centimeter } \\ \mathrm{cpm} & \text { counts per minute } \\ \mathrm{dis} / \mathrm{s} & \text { disintegrations per second } \\ \mathrm{ft} & \text { foot } \\ \mathrm{g} & \text { gram } \\ \mathrm{ha} & \text { hectare } \\ \mathrm{in} . & \text { inch } \\ \mathrm{kg} & \text { kilogram } \\ \mathrm{km} & \text { kilometer } \\ \mathrm{lb} & \text { pound } \\ \mathrm{m} & \text { meter } \\ \mathrm{m}^{2} & \text { square meter } \\ \mathrm{m}^{3} & \text { cublc meter } \\ \mathrm{mi} & \text { mile } \\ \mu \mathrm{R} / \mathrm{h} & \text { microroentgens per hour } \\ \mathrm{pCi} / \mathrm{g} & \text { picocuries per gram } \\ \mathrm{t} & \text { tonne } \\ \mathrm{yd}^{3} & \text { cubic yards }\end{array}$




\subsection{INTRODUCTION}

The Weldon Spring Site (WSS) is a U.S. Department of Energy (DOE) surplus facility located in St. Charles County, Missouri approximately $48 \mathrm{~km}$ (30 $\mathrm{mi})$ west of the city of st. Louis. The site comprises two separate facilities approximately $6.4 \mathrm{~km}$ (4 mi) apart -- the 21-ha (52-acre) Raffinate Pits facility and the 3.4-ha (9-acre) Quarry. The Weldon Spring Raffinate Pits (WSRP) facility is located approximately $22 \mathrm{~km}(14 \mathrm{mi})$ southwest of the city of St. Charles and is accessed from Missouri state Route 94. The site is approximately $3.2 \mathrm{~km}$ ( $2 \mathrm{mi}$ ) southwest of the junction of Route 94 and Route 40. Both the Raffinate Pits and the Quarry are presently used for the storage of low-level radioactive residues, waste materials, and contaminated rubble. The general location of the two properties is illustrated in Figure 1-1. DOE is also responsible for vicinity properties near the Raffinate Pits and Quarry that may have become contaminated as a result of operations at the facilities.

The WSRP facility includes four pits covering a total of approximately 11 ha $(27$ acres). As shown in Figure $1-2$, the site is bordered on all sides by U.S. Army-owned land. The western half of the site is bounded by a large Army Reserve and National Guard training area, and the eastern half is bounded by the Army-owned Weldon Spring Chemical Plant, inoperative since 1966. To the north beyond the Army-controlled area is the August A. Busch Wildlife Area, a large public park which is administered by the Missouri Department of Conservation. The Weldon Spring Wildlife Area, also administered by the Missouri Department of Conservation, lies to the south. Access to the WSRP site is controlled by a 2-m-high (7-ft-high) fence enclosing the DOE property. Each of the pits is also encircled by a smaller interior fence. Figure $1-3$ shows the four pits, their relative size and location, and other site features. 


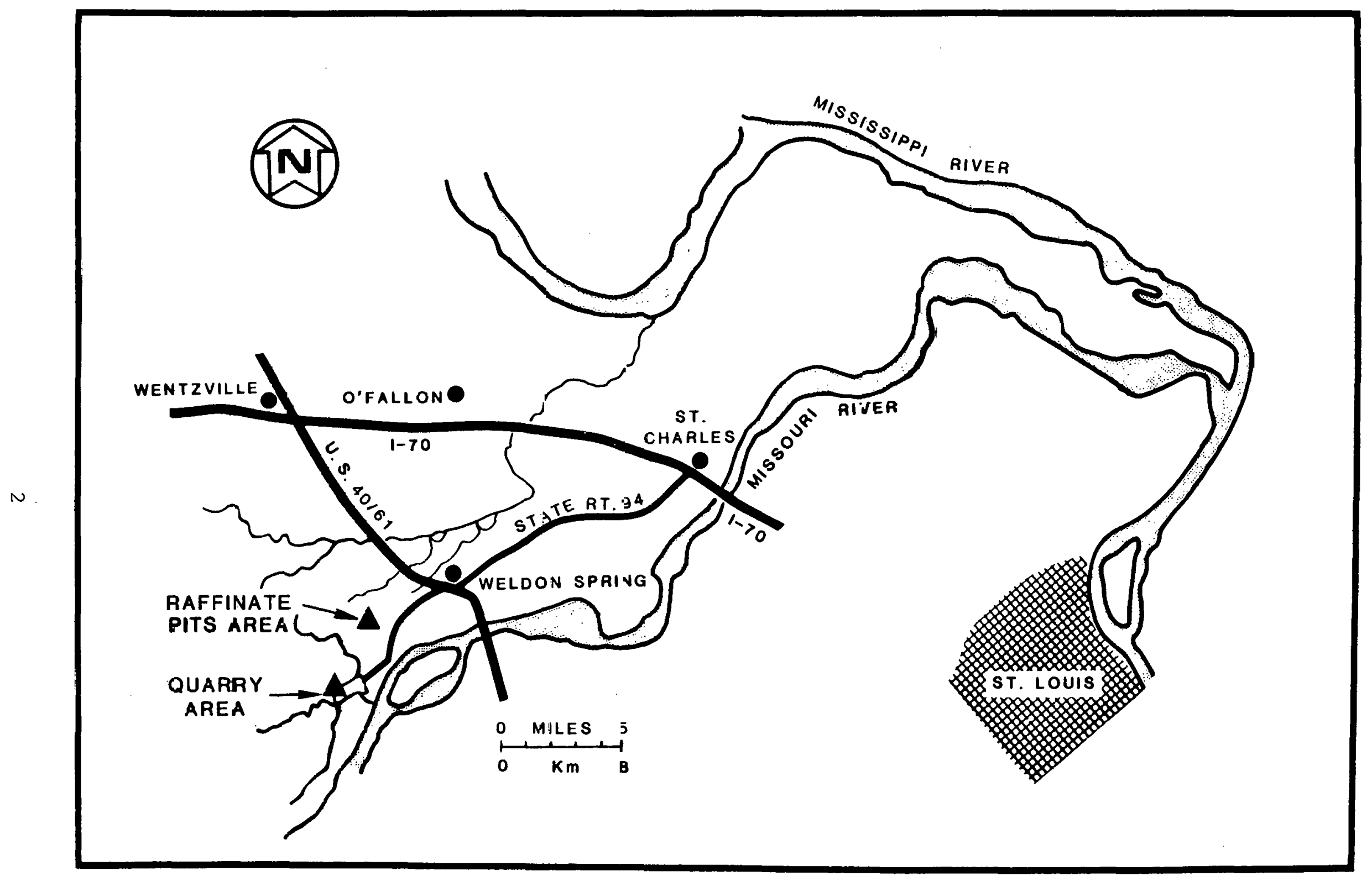

FIGURE 1-1 WELDON SPRING SITE (WSS) AREA MAP 


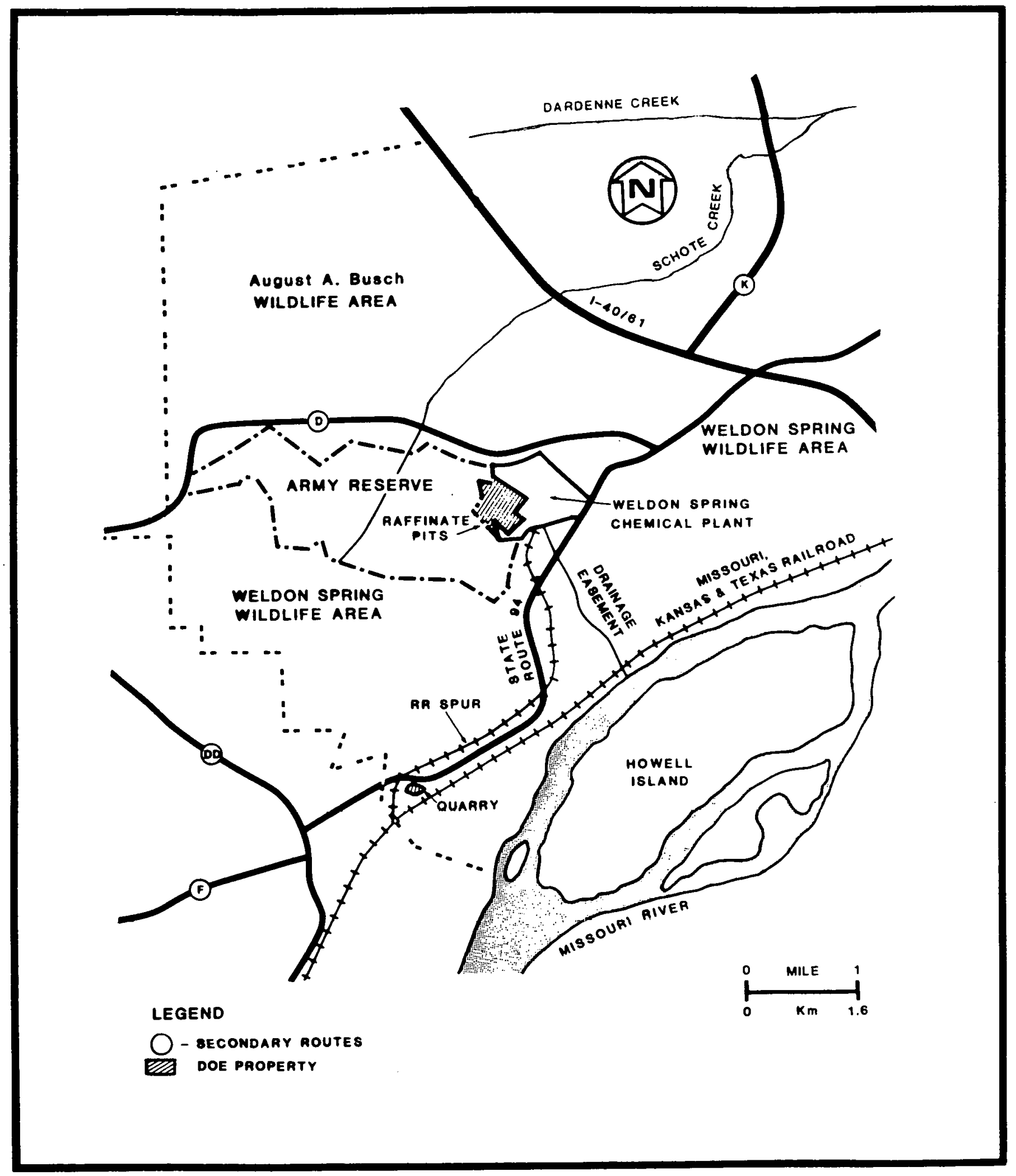

FIGURE 1-2 WSS VICINITY MAP 


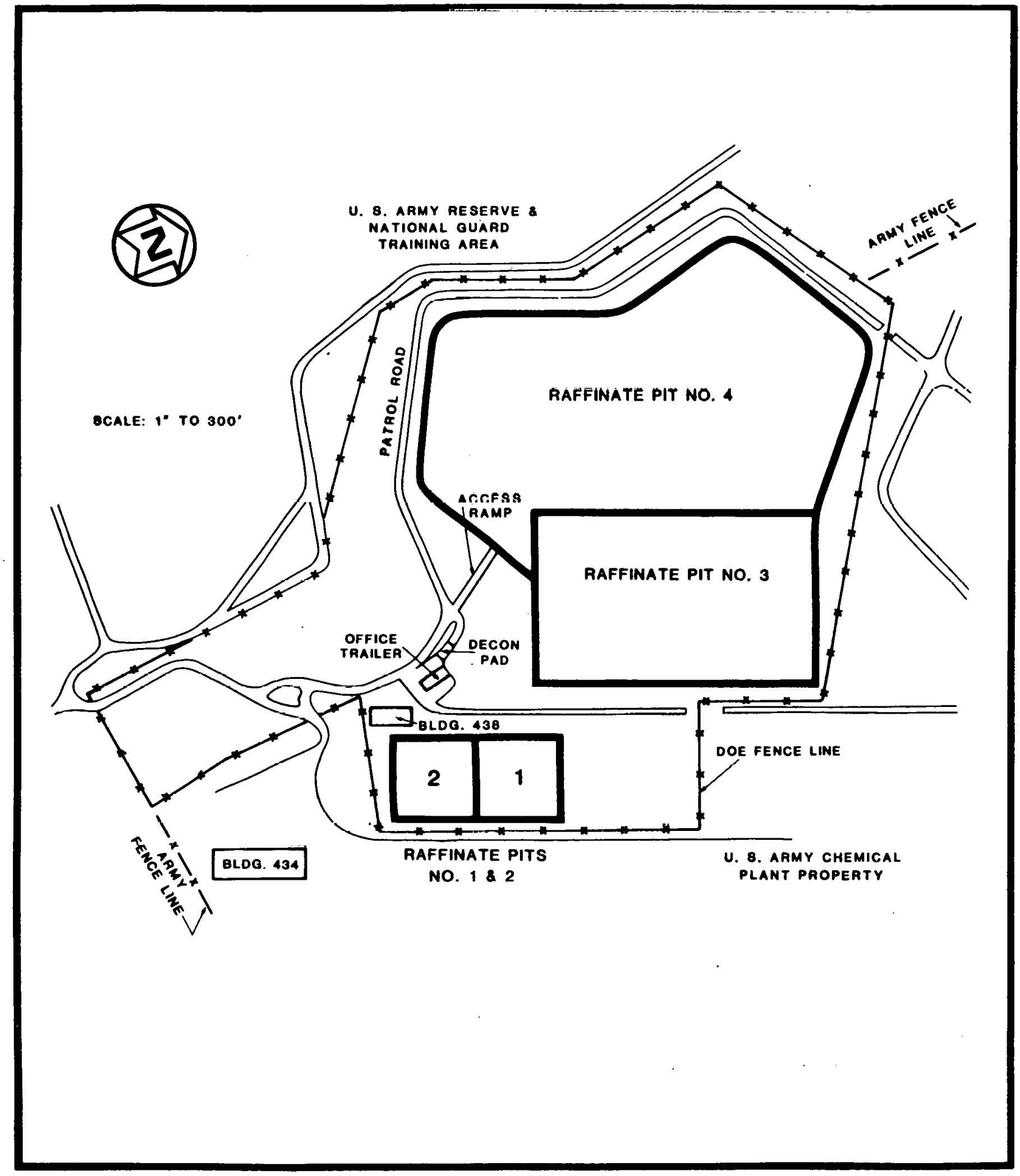

FIGURE 1-3 WSS RAFFINATE PIT AREA 
Since October 1981, both the WSRP site and the Quarry have been maintained by Bechtel National, Inc. (BNI), which was chosen by DOE as the Project Management Contractor (PMC) for the site. As part of its duties as PMC, BNI maintains security, performs. maintenance as required, and carries out an environmental monitoring program through close cooperation with its radiological support subcontractor, Eberline Instrument Corporation (EIC). The radiological survey presented in this document was conducted in support of repair work on Pit 4 and other site construction activities as well as investigations of site geology. It was the first phase of the three-phase radiological characterization of the wSS. Surveys of the Quarry and the vicinity properties will follow. 


\subsection{SITE BACKGROUND AND DESCRIPTION}

A brief history of the Raffinate Pits and a description of their present condition are provided in this section.

\subsection{SUMMARY OF SITE HISTORY}

In 1956 the Atomic Energy Commission (AEC), predecessor to DOE, acquired about 89 ha (220 acres) of the original Weldon spring Ordnance Works Plant from the Department of the Army (DOA) to develop a uranium feed materials plant. With the closing of the Mallinckrodt Chemical Works' Destrehan Street (st. Louis, Missouri) uranium ore processing facility in 1957, all operations at this facility were transferred to the AEC's new facility, called the Weldon Spring Chemical Plant. Mallinckrodt, Inc. operated this facility for the AEC from 1957 until operations ceased in 1966.

The Chemical Plant was an integrated facility which converted uranium ore concentrates and recycled scrap to pure uranium trioxide, intermediate compounds, and uranium metal. An average of approximately $14,500 \mathrm{t}(16,000$ tons) of uranium materials were processed at this plant annually. A relatively small amount of thorium was also processed. The wastes generated during operations were stored in the four raffinate pits located adjacent to the plant. The residues discharged to the pits consisted of raffinates from uranium refining operations, washed magnesium fluoride slag residues from uranium metal production, and raffinate solids from the processing of thorium recycle materials.

The raffinates were neutralized with lime and pumped to the pits as a slurry. The solids, principally acid-insoluble compounds in the feed materials (chiefly silica), settled in the pits. The supernatant liquid overflowed to the Chemical plant process sewer, where it was mixed with storm water and sewage treatment 
effluent. It was then discharged from the sewer outfall into a small stream that flows approximately $2.4 \mathrm{~km}(1.5 \mathrm{mi})$ to the Missouri River.

In 1966 the AEC shut down the Chemical Plant and in 1967 returned the facility to the DOA for planned use as a defoliant production plant. The Army started removing equipment and decontaminating the site buildings in 1968. About $4,600 \mathrm{~m}^{3}$ $\left(6,000 \mathrm{yd}^{3}\right)$ of contaminated material were hauled to the Quarry. An undetermined amount of contaminated material, consisting of piping, ducting, drums, and other scrap material, was also dumped in Raffinate Pit 4. The defoliant project was cancelled in 1969 before any herbicide was produced. The DOA retained the responsibility for the land and the facilities referred to as the Chemical Plant. The 21-ha (52-acre) tract encompassing the four raffinate pits was transferred back to the AEC. The 3.4-ha (9-acre) Quarry also remained under the control of the AEC. The AEC, and later DOE, contracted with National Lead Company of Ohio (NLO) to periodically visit the Raffinate Pits and Quarry to maintain the sites, provide security, and perform environmental monitoring. These responsibilities were assumed by BNI in October 1981 .

\subsection{DESCRIPTION OF THE RAFFINATE PITS}

The surface area, volume, and contents of the Raffinate Pits are summarized in Table 2-1.

The pit drains and all transfer lines from the pits to the Chemical plant storm sewer have been sealed (Ref. 1). Water covers the pit residues for most of the year, depending upon temperature and precipitation. In the summer months, the surface water in Pits 1 and 2 may evaporate, leaving a dry and cracked surface. The level of water in Pits 3 and 4 fluctuates, but some surface water is always present. Water has never overflowed from any of the pits except for a designed overflow from Pit 3 to Pit 4 during periods of heavy rainfall. 
TABLE 2-1

SURFACE AREA, VOLUME, AND CONTENTS

OF THE WELDON SPRING RAFFINATE PITS

\begin{tabular}{lccccc}
\hline Pit & Constructed & $\begin{array}{c}\text { Surface } \\
\text { Area } \\
\text { (acres) }\end{array}$ & $\begin{array}{c}\text { Total Pit } \\
\text { Volume } \\
\left(\mathrm{yd}^{3}\right)\end{array}$ & $\begin{array}{c}\text { Total Waste } \\
\text { Volume } \\
\left(\mathrm{yd}^{3}\right)\end{array}$ & $\begin{array}{c}\text { Percent } \\
\text { Filled }\end{array}$ \\
\hline 1 & 1958 & 1.2 & 18,500 & 17,400 & 94 \\
2 & 1958 & 1.2 & 18,500 & 17,400 & 94 \\
3 & 1.959 & 8.4 & 166,700 & 129,600 & 78 \\
4 & 1964 & $\underline{15.0}$ & $\underline{\underline{444,400}}$ & $\underline{\underline{55,600}}$ & 12 \\
& TOTAL & $\underline{\underline{25.8}}$ & $\underline{\underline{648,100}}$ & $\underline{\underline{20,000}}$ & \\
\hline
\end{tabular}


In 1982 a portion of the dike around Pit 4 was repaired to stabilize a shallow circular arc slide. During this activity, site roads were repaired and a temporary decontamination facility was constructed. In addition, utilities (power, potable water, and telephone) were installed to support construction and monitoring activities. The radiological survey presented in this document was undertaken in support of these construction activities and a technical evaluation of site geology . 


\subsection{SURVEY PROCEDURES}

The radiological survey presented here was conducted by BNI/EIC in June 1982 with follow-up work in the winter of 1982-83. The survey grid system corresponded with the AEC grid which is $28^{\circ}-19^{\prime}-33^{\prime \prime}$ east of true north. The grid was established on $30-\mathrm{m}$ (100-ft) intervals which were further reduced during the 1982-83 survey to $(6-\mathrm{m})(20-\mathrm{ft})$ or $1.5-\mathrm{m}(5-\mathrm{ft})$ intervals over areas of elevated readings.

\subsection{FIELD MEASUREMENTS}

Gamma measurements were made near surface ( $30 \mathrm{~cm}$ or $1 \mathrm{ft}$ ) and $1 \mathrm{~m}$ from the ground surface. Near-surface measurements were made using a 5-cm x 5-cm (2-in. x 2-in.) sodium-iodide (NaI) detector (EIC Model SPA-3).

The detector was mounted in a probe assembly surrounded with a conical lead shield to reduce the gamma intensity through the sides, thus providing a downward directional response. The detector was coupled with an EIC PRS-1 ratemeter/scaler. The average background reading was $6000 \mathrm{cpm}$.

Beta-gamma dose rate measurements were llade al lihe ground surface using a thin-window (GM) probe (EIC Model HP-210) coupled.with a ratemeter/scaler (EIC Model PRS-1). The average background in the landfill area using an HP-210 probe was $50 \mathrm{cpm}$.

Gamma exposure rates at $1 \mathrm{~m}$ ( $3 \mathrm{ft}$ ) above the ground were also made using an EIC Model SPA-3. Measurements were taken in the center of the grid points at $30-m(100-f t)$ intervals. A pressurized ion chamber (PIC) was also used to make a series of measurements to obtain the calibration factor used to estillate the gamma exposure rate from NaI detector readings in $\mu R / h$. The PIC response is proportional to exposure in roentgens. The average background using the PIC in the Weldon Spring area was $9 \mu R / h$. 
Initial gamma measurements were made on the grid points at 30-m (100-ft) intervals. Walkover surface scans were also conducted. Locations of elevated radiations were noted and additional measurements were taken as necessary at 6-m (20-ft) intervals to define more precisely the boundaries of contaminated surface soil.

Further surveys were conducted following construction activities on site. Beta-gamma measurements were made at 6-m (20-ft) intervals in areas previously identified and at $1.5-m$ (5-ft) intervals where elevated readings were indicated. Gamma exposure rates were obtained at 45 of the 64 center grid points.

During December gamma scans were performed and the radiation readings logged in 12 shallow boreholes. The holes were $15 \mathrm{~cm}$ (6 in.) in diameter and $122 \mathrm{~cm}$ (48 in.) deep. The exceptions are holes W99,000 N50,600 and W98,800, N50,600 which were hand augered to a depth of $91 \mathrm{~cm}$ (36 in.). Timed gamma measurements were made at $15-\mathrm{cm}(6-\mathrm{in}$.$) vertical intervals.$

In January and February 1983, an additional 16 boreholes were gamma-logged. These boreholes were drilled in support of the geotechnical activities on site. The boreholes were 15-cm (6-in.) diameter holes cased with 10-cm (4-in.) schedule 40 PVC or 20-cm (8-in.) diameter holes cased with 7-cm (3-in.) schedule 40 PVC. These boreholes varied in depth between $5.8 \mathrm{~m}$ ( $228 \mathrm{in.}$ ) to $9.5 \mathrm{~m}(372 \mathrm{in.})$.

Three measurements were made at each geotechnical borehole location: 1) a background reading with the detector positioned approximately $1 \mathrm{~m}$ above the ground, 2) a reading with the. detector positioned on the surface of auger turnings removed from the holes (identified as auger spoils), and 3 ) readings of the gamma level as a function of depth in each borehole. A 5-cm x 5-cm (2-in. x 2-in.) NaI detector coupled with an EIC PRS-l ratemeter/scaler was used. 


\subsection{SAMPLE COLLECTION AND ANALYSIS}

During the fall of 1982, 120 surface and 34 trench sidewall soil samples were collected and sent to off-site EIC facilities for analysis. The samples, weighing approximately $700 \mathrm{~g}$ each, were analyzed wet and then dried and pulverized in a ball mill. The dried samples of approximately $400 \mathrm{~g}$ each were analyzed for uranium-238, radium-226, and thorium-232 in a 10-minute count. Nineteen of the 120 surface soil samples were also analyzed for thorium-230.

Fifty-nine surface soil samples (ss-l to ss-59) were collected along the road from the southernmost gate. Samples were obtained at $6.1-\mathrm{m}(20-\mathrm{ft})$ intervals on the center-line of the road and $3 \mathrm{~m}$ ( $10 \mathrm{ft}$ ) to either side. An additional 60 surface soil samples were collected from another 59 locations, ten of which were in areas of elevated gamma readings as identified by the gamma survey. The remainder of the samples were taken from the dikes and along the property boundary.

Thirty-four samples were collected from the sidewalls of 11 trenches. These samples were obtained from soil profiles of 30-cm (l-ft) increments to a depth of $90 \mathrm{~cm}(3 \mathrm{ft})$. The exception is Trench 11 in which buried trash was encountered.

Sludge samples from each of the four pits were analyzed for 29 elements, nitrates, fluorides, chlorides, sulfates, hydroxides, $\mathrm{pH}$, and the following radionuclides: radium-226, radium-228, thorium-232, thorium-230, uranium-238, uranium-234, and uranium-235. 


\subsection{SURVEY RESULTS}

This section presents the results of the direct measurements and soil sample analysis undertaken in this survey. All direct field measurements in this report represent gross readings. Background gamma levels averaged $6000 \mathrm{cpm}$.

\section{1 DIRECT MEASUREMENTS}

Results of direct gamma measurements are presented in Figure 4-1. The walkover scan identified several areas with elevated readings. Areas with the highest readings contained scrap material or were patchy areas void of vegetation. These areas are readily observable on site.

In November and December near-surface gamma- and surface beta-gamma characterization were conducted on a $1.5-m$ ( $5-f t$ ) grid in areas where elevated readings were identified. Surveys conducted on the $1.5-\mathrm{m}(5-\mathrm{ft})$ grid facilitated differentiation between background and elevated readings in areas where contamination was localized. Hatched areas in Figure 4-1 indicate areas where near-surface readings exceeded three times background.

Exposure rates were measured in 45 out of a possible 64 grid center locations. Two readings were in excess of $60 \mu \mathrm{R} / \mathrm{h}$ (N98,250, W51, 150 and N98,150, W50,950) which is the Nuclear Regulatory Commission (NRC) standard for continuous exposure to an individual in the general population (Ref. 2). The average reading for the site was $23 \mu \mathrm{R} / \mathrm{h}$, which is below the standard. Exposure levels are indicated in Figure 4-2.

The results of gamma scintillation measurements performed in boreholes indicate that the contamination is confined to the upper $1 \mathrm{~m}$ (39 in.) of soil. Gamma readings taken in the shallow boreholes drilled in areas of elevated surface readings ( $\mathrm{SB}-1$ to $\mathrm{SB}-8)$ were reduced by up to factors of six in the first $30 \mathrm{~cm}$ 


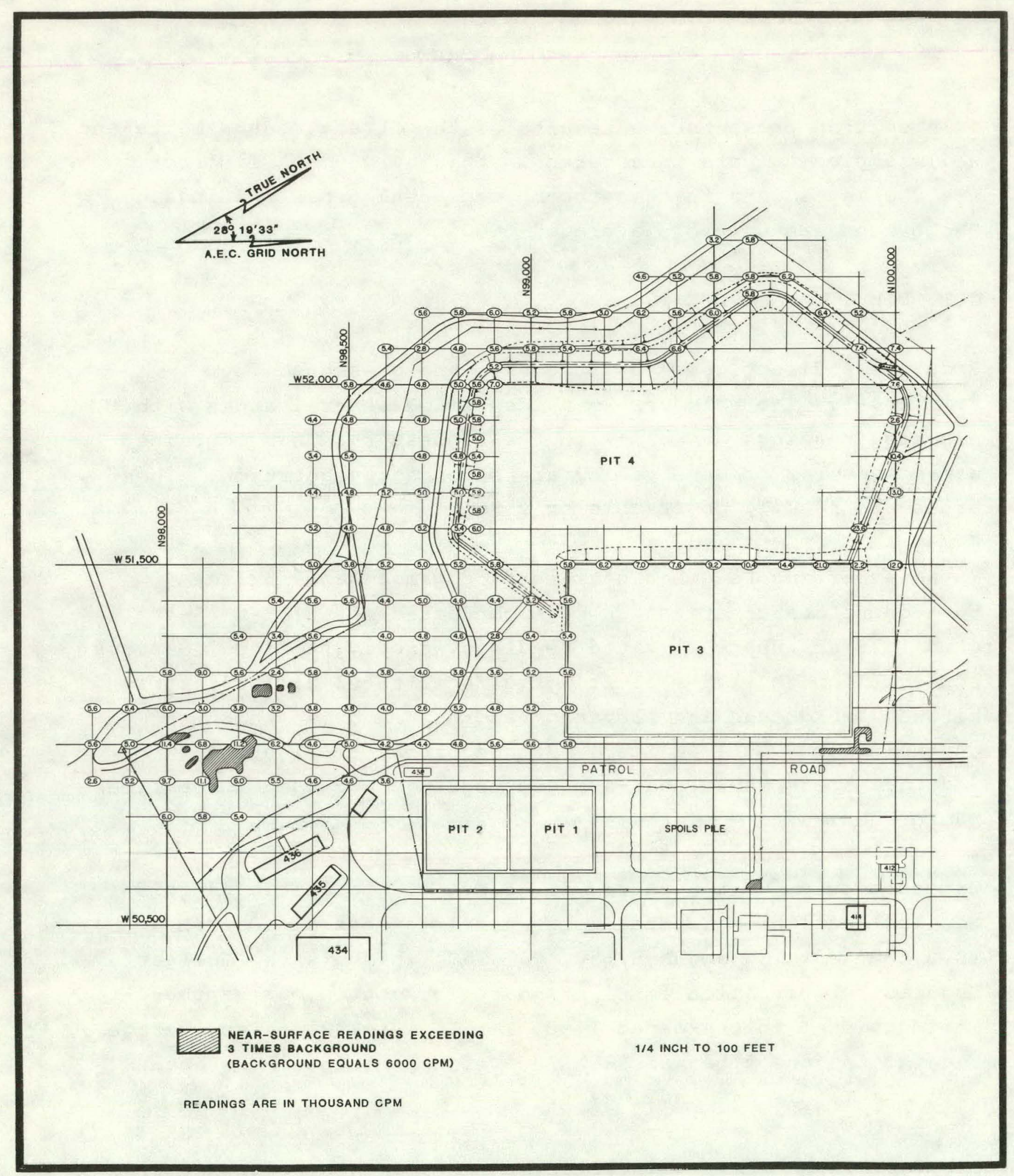

$\begin{array}{ll}\text { FIGURE 4-1 } & \text { RESULTS OF DIRECT GAMMA MEASUREMENTS AT THE } \\ \text { WSRP SITE }\end{array}$ 


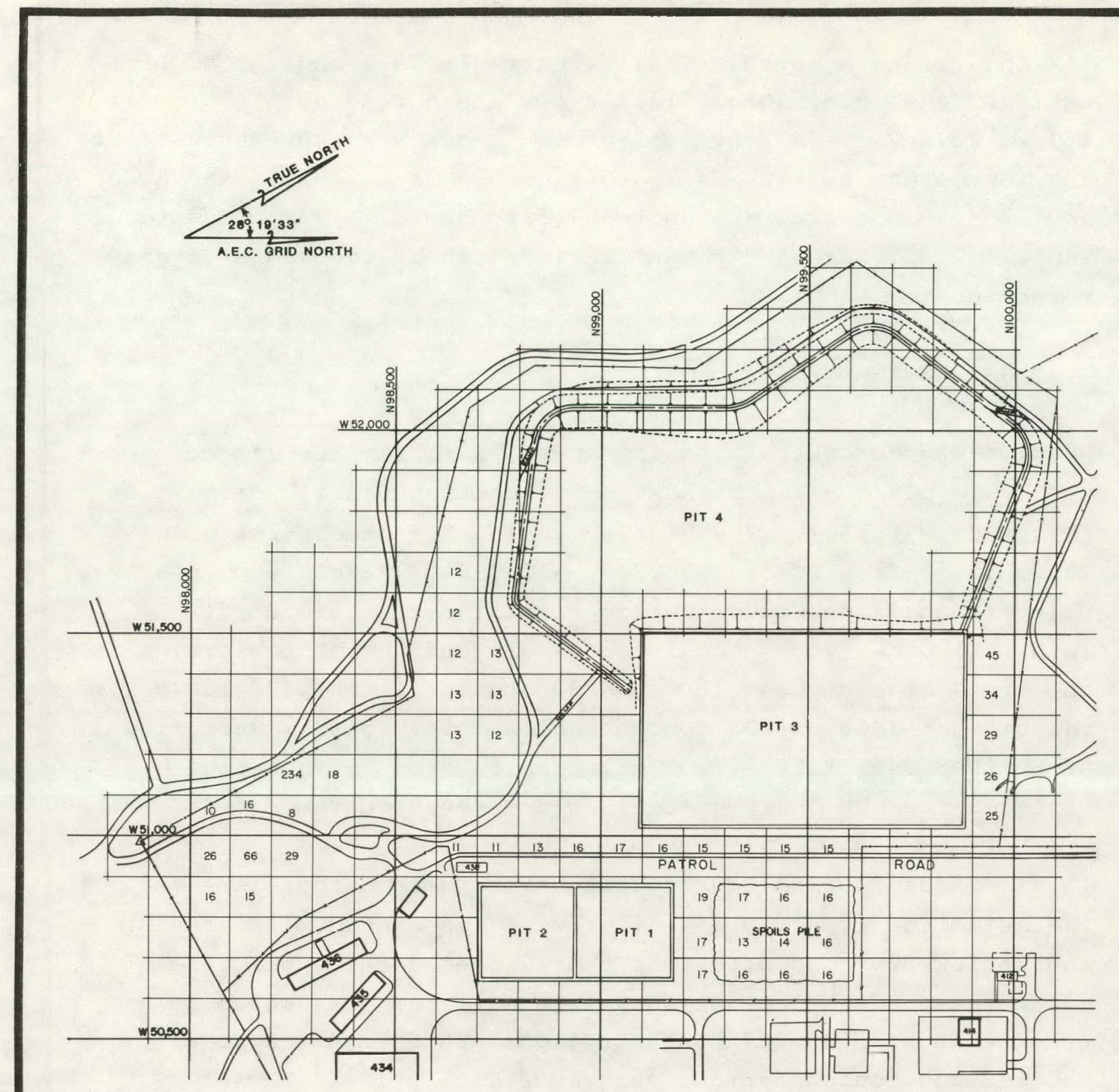

$1 / 4$ INCH TO 100 FEET

FIGURE 4-2 EXPOSURE RATES $(\mu R / h)$ AT THE WSRP SITE 
(12 in.) of hole depth. Shallow borehole SB-2 had the highest surface gamma reading of $319,216 \mathrm{cpm}$ and a reading at $30 \mathrm{~cm}$ ( 1 $\mathrm{ft}$ ) of $73,262 \mathrm{cpm}$. Table 4-1 presents gamma measurements of the shallow boreholes. Gamma log background measurements and auger spoils readings from the geotechnical boreholes are presented in Table 4-2. Figure 4-3 shows the location of the gamma-logged boreholes.

\subsection{SAMPLE ANALYSIS}

Uranium-238 concentrations in surface soil samples ranged from 2 to $34,090 \mathrm{pCi} / \mathrm{g}$. The highest concentration was found in ss-66 (N98,250, W51,150). The highest radium-226 concentration was $261.9 \mathrm{pCi} / \mathrm{g}$ from SS-65 (N98,245, W50,y9b). Kesampling from this point reduced the concentration of radium-226 to $8.3 \mathrm{pCi} / \mathrm{g}$. This is indicative of the inhomogeneity of the contamination in the area. The highest thorium-230 concentration, $370 \mathrm{pCi} / \mathrm{g}$, and the highest thorium-232 concentration, $454.9 \mathrm{pCi} / \mathrm{g}$, were from SS-60 (N98,045, W51,000). Soil samples from 15 locations exceeded the DOE draft guidelines presented in Table 4-3.

In all cases thorium-230 concentrations were either less than the guideline (see Table 4-3) or were associated with uranium and radium-226 concentrations that exceeded the applicable guidelines. This indicates that remedial actions based on uranium and radium-226 concentrations would ensure removal of thorium-230 concentrations that exceed $15 \mathrm{pCi} / \mathrm{g}$. Therefore, monitoring for thorium-230 during remedial actions outside the raffinate pits would be required on a limited basis only.

Soil sample analysis and background levels of uranium-238, radium-226, thorium-230, and thorium-232 are presented in Tables 4-4 and 4-5. The locations where surface soil samples were collected are indicated in Figure 4-4. The locations of those samples exceeding guidelines are shown in Figure 4-5. 
TABLE 4-1

GAMMA LOG OF SHALLOW BOREHOLES AT THE WSRP SITE

(Readings in cpm)

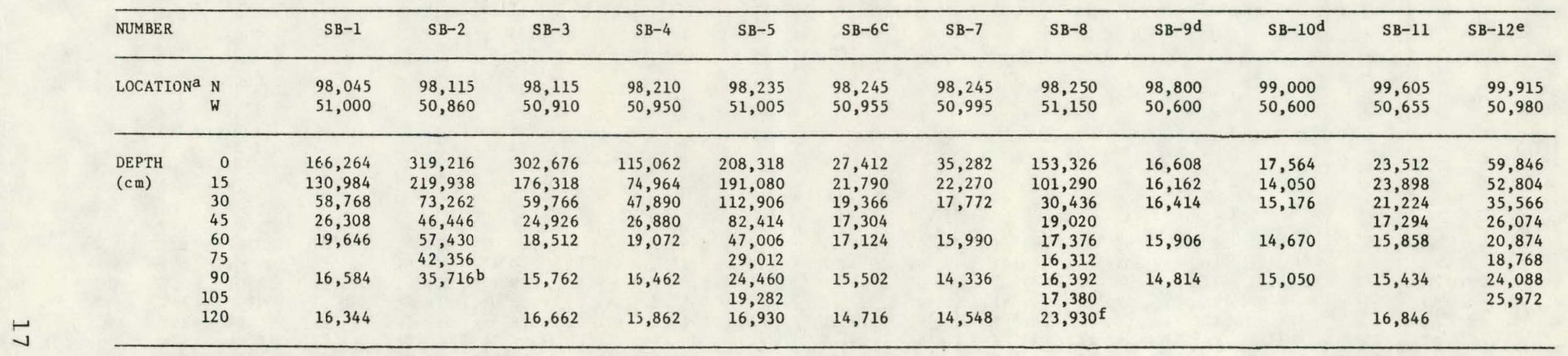

a Sampling locations are shown on Figure 4-3.

bCave $1 \mathrm{n}$

cPVC sleeve

$\mathrm{d}_{\text {Hand }} \mathrm{drilled}$ to $90 \mathrm{~cm}(36 \mathrm{ln}$.

eold hole with sediment

f Sediment 
TABLF. $4-2$

GAMMA LOG OF GEOTECHNICAL BOREHOLES AT THE WSRP SITE (Readings in cpm)

\begin{tabular}{|c|c|c|c|c|c|c|c|c|c|c|c|c|c|c|c|c|c|}
\hline \multicolumn{2}{|l|}{ NJMBER } & $S B-1^{b}$ & $S B-2 C$ & $\mathrm{SB}-3^{\mathrm{C}}$ & $S B-4^{b}$ & $S B-5^{C}$ & $\mathrm{SB}-6 \mathrm{C}$ & $\mathrm{SB}-7^{\mathrm{C}}$ & $\mathrm{SB}-8^{\mathrm{C}}$ & $S B-9 C$ & $\mathrm{SB}-10^{C}$ & $S B-11^{C}$ & $\mathrm{SB}-12^{\mathrm{C}}$ & $\mathrm{SB}-13^{\mathrm{C}}$ & $S B-14^{C}$ & $S B-15^{C}$ & $S B-16^{b}$ \\
\hline \multicolumn{2}{|c|}{ LOCATIONa $\mathrm{N}$} & $\begin{array}{l}98,470 \\
50,940\end{array}$ & $\begin{array}{l}98,7 \div 0 \\
51,6=0\end{array}$ & $\begin{array}{l}98,760 \\
51,970\end{array}$ & $\begin{array}{l}98,825 \\
51,250\end{array}$ & $\begin{array}{l}99,000 \\
51,200\end{array}$ & $\begin{array}{l}99,220 \\
50,750\end{array}$ & $\begin{array}{l}99,230 \\
50,980\end{array}$ & $\begin{array}{l}99,250 \\
52,050\end{array}$ & $\begin{array}{l}99,275 \\
52,140\end{array}$ & $\begin{array}{l}99,420 \\
51,025\end{array}$ & $\begin{array}{l}99,595 \\
50,805\end{array}$ & $\begin{array}{l}99,600 \\
50,950\end{array}$ & $\begin{array}{l}99,880 \\
51,520\end{array}$ & $\begin{array}{l}99,940 \\
51,250\end{array}$ & $\begin{array}{r}100,010 \\
52,000\end{array}$ & $\begin{array}{r}100,050 \\
52,100\end{array}$ \\
\hline \multicolumn{18}{|c|}{ DEPTH } \\
\hline 0 & 0 & 4,962 & $9,5 \approx 4$ & 7,790 & 7,350 & 9,326 & 9,868 & 14,746 & 9,178 & 4,736 & 9,464 & 10,376 & 6,476 & 30,284 & 14,218 & 14,460 & 10,502 \\
\hline 12 & 30 & 12,718 & $14,5 \in 4$ & 13,718 & 14,048 & 14,344 & 12,414 & 18,070 & 11,684 & 2,260 & 11,704 & 12,770 & 11,892 & 26,450 & 14,974 & 12,308 & 14,216 \\
\hline 24 & 61 & 15,366 & 15,512 & 15,718 & 15,254 & 15,606 & 12,774 & 16,292 & 12,404 & 2,856 & 13,084 & 14,302 & 13,526 & 16,640 & 14,458 & 12,392 & 15,616 \\
\hline 36 & 91 & 15,152 & 15,780 & 15,430 & 14,372 & 15,798 & 13,434 & 15,166 & 12,322 & 7,524 & 13,768 & 14,558 & 13,480 & 15,412 & 15,040 & 12,454 & 16,406 \\
\hline 48 & 122 & 14,474 & 16,214 & 14,470 & 14,180 & 15,056 & 14,098 & 15,584 & 12,738 & 10,954 & 14,000 & 14,354 & 13,168 & 14,980 & 15,310 & 13,574 & 16,364 \\
\hline 60 & 152 & 13,466 & 15,524 & 13,818 & 13,410 & 14,852 & 13,678 & 15,380 & 13,278 & 12,554 & 14,642 & 13,900 & 14,072 & 15,802 & 15,716 & 13,938 & 15,988 \\
\hline 72 & 183 & 12,248 & 14,724 & 13,360 & 13,044 & 14,462 & 13,858 & 15,194 & 12,662 & 11,006 & $14: 230$ & 14,298 & 13,950 & 15,856 & 15,728 & 14,096 & 15,294 \\
\hline 84 & 213 & 12,278 & 14,034 & 13,474 & 12,822 & 14,358 & 13,202 & 14,722 & 13,132 & 10,076 & 14756 & 14,552 & 14,164 & 14,760 & 14,466 & 14,464 & 14,650 \\
\hline 96 & 244 & 11,466 & $13, \epsilon ; 0$ & 13,050 & 11,894 & 13,870 & 12,220 & 14,384 & 12,908 & 11,662 & $14 \quad 232$ & 14,676 & 13,516 & 15,232 & 14,568 & 14,480 & 13,410 \\
\hline 108 & 274 & 10,378 & 13,858 & 11,330 & 10,264 & 13,034 & 13,246 & 13,706 & 12,434 & 12,042 & 14.344 & 14,220 & 13,488 & 15,396 & 13,956 & 14,174 & 12,458 \\
\hline 120 & 305 & 10,502 & 13,572 & 11,370 & 10,412 & 13,442 & 13,380 & 14,460 & 12,804 & 11,738 & 14,540 & 13,336 & 13,584 & 15,236 & 12,016 & 14,810 & 12,304 \\
\hline 132 & 335 & 10,410 & 13,670 & 11,306 & 10,982 & 13,834 & 13,218 & 14,492 & 13,688 & 10,586 & 15,084 & 13,318 & 13,592 & 15,734 & 11,530 & 15,666 & 11,822 \\
\hline 144 & 366 & 9,976 & 12,610 & 11,610 & 10,748 & 13,494 & 13,014 & 15,246 & 13,426 & 9,408 & 14.726 & 13,110 & 13,660 & 15,070 & 12,170 & 15,942 & 11,530 \\
\hline 156 & 396 & 9,936 & 12,238 & 12,132 & 10,790 & 13,250 & 12,836 & 15,408 & 13,684 & 9,518 & 14.678 & 12,784 & 13,070 & 16,136 & 12,122 & 15,216 & 11,992 \\
\hline 168 & 427 & 9,638 & 12,130 & 12,050 & 10,734 & 12,532 & 13,054 & 15,146 & 14,684 & 9,918 & 12,980 & 12,744 & 12,254 & 16,708 & 11,624 & 15,506 & 12,260 \\
\hline 180 & 457 & 10,000 & 12,100 & 12,038 & 9,908 & 12,274 & 12,948 & 13,104 & 14,674 & 10,340 & 14,792 & 12,336 & 11,268 & 16,134 & & 15,778 & 12,328 \\
\hline 192 & 488 & 10,466 & 13,088 & 12,986 & 10,808 & 11,948 & 12,382 & 11,846 & 13,456 & 10,216 & 14,496 & 11,760 & 10,972 & 16,364 & & 15,590 & 12,132 \\
\hline 204 & 518 & 10,442 & 13,206 & 13,834 & 11,860 & 12,610 & 12,012 & 11,324 & 13,046 & 9,806 & 14,256 & 11,142 & 9,838 & 15,256 & & 16,314 & 12,062 \\
\hline 216 & 549 & 10,674 & 13,100 & 13,528 & 11,058 & 12,588 & 11,522 & 11,098 & 13,666 & 9,702 & 14,456 & 8,710 & 11,504 & 15,256 & & 15,712 & 11,272 \\
\hline 228 & 579 & 10,738 & $12, \subseteq 52$ & 12,698 & 10,530 & & 11,666 & 11,178 & 14,660 & 10,342 & 13,832 & 8,354 & 9,270 & 14,516 & & 15,874 & 7,030 \\
\hline 240 & 610 & 11,360 & & & 10,390 & & & & & 8,936 & & & & & & & 7,314 \\
\hline 252 & 640 & 11,338 & & & 9,282 & & & & & 7,466 & & & & & & & 7,202 \\
\hline 264 & 671 & 10,360 & & & 6,408 & & & & & 6,070 & & & & & & & 6,662 \\
\hline 276 & 701 & 10,956 & & & 5,224 & & & & & 5,856 & & & & & & & 6,694 \\
\hline 288 & 732 & 10,640 & & & 4,418 & & & & & & & & & & & & 5,468 \\
\hline 300 & 762 & 10,552 & & & 5,980 & & & & & & & & & & & & 6,186 \\
\hline 312 & 792 & 10,102 & & & 6,370 & & & & & & & & & & & & 5,630 \\
\hline 324 & 823 & 9,920 & & & $3,682^{d}$ & & & & & & & & & & & & 6,418 \\
\hline 336 & 853 & 9,818 & & & 3,630 & & & & & & & & & & & & 6,670 \\
\hline 348 & 884 & 10,520 & & & 2,886 & & & & & & & & & & & & 6,108 \\
\hline 360 & 914 & 10,492 & & & 1,892 & & & & & & & & & & & & 8,958 \\
\hline 372 & 945 & 9,972 & & & 1,584 & & & & & & & & & & & & 6,038 \\
\hline 384 & 975 & 11,236 & & & & & & & & & & & & & & & 5,476 \\
\hline 396 & 1006 & & & & & & & & & & & & & & & & 3,440 \\
\hline
\end{tabular}

a Borehole locations are shown on Figure 4-3.

b $6-i n$. diameter hole with +1 in. schedule 40 PVC

c8-in. diameter hole with 3-in. schedule 40 PVC.

dProbe was in water. 


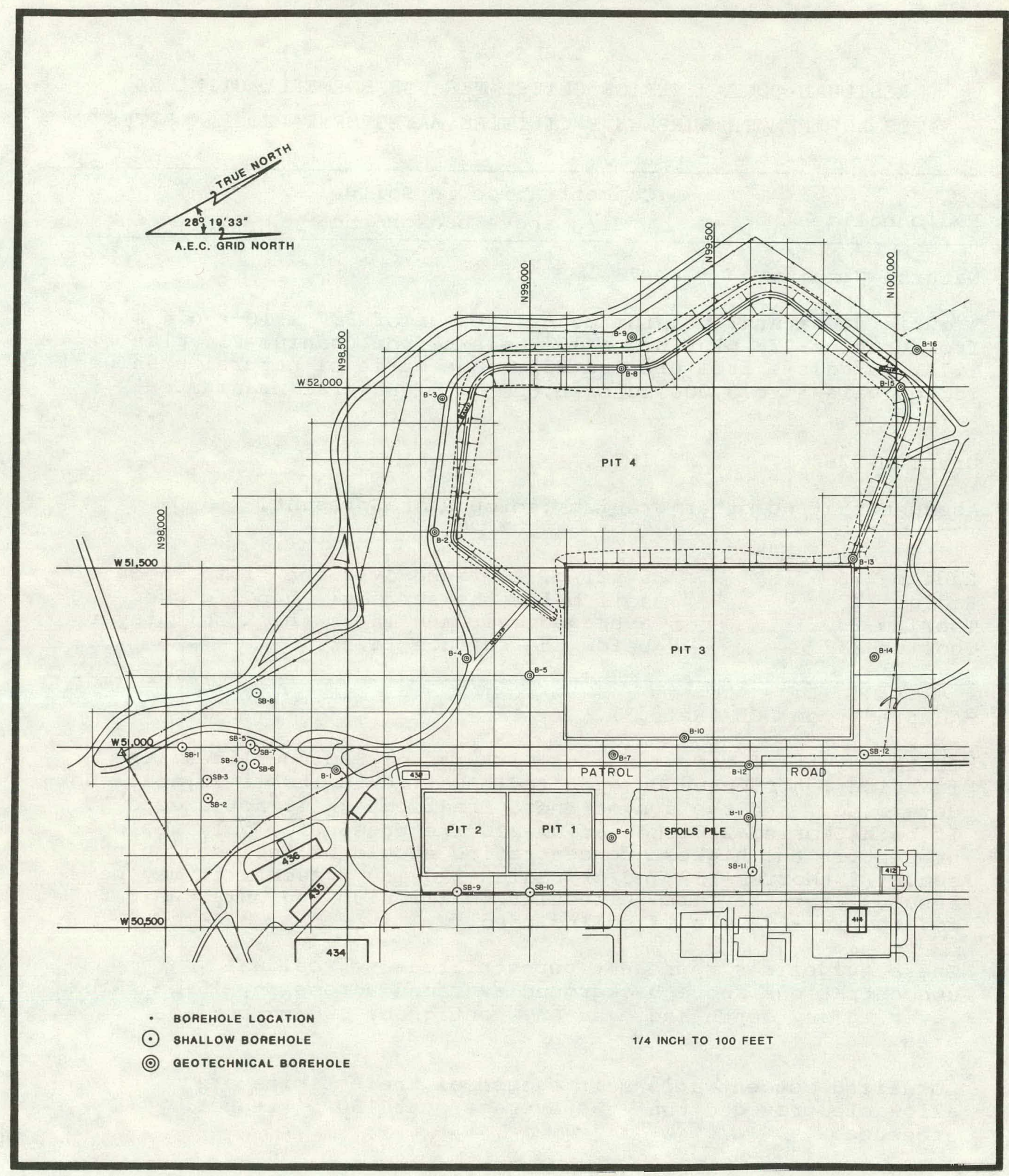

FIGURE 4-3 LOCATION OF GAMMA-LOGGED BOREHOLES AT THE WSRP SITE 
TABLE $4-3$

RESIDUAL CONTAMINATION GUIDELINES FOR FORMERLY UTILIZED

SITES AND REMOTE SURPLUS FACILITIES MANAGEMENT PROGRAM SITES ${ }^{a}$

\begin{tabular}{ll} 
Radionuclide & Concentration in Soil \\
& $(\mathrm{pci} / \mathrm{g} \text { above background })^{b}, \mathrm{c}, \mathrm{d}$ \\
\hline
\end{tabular}

Natural Uranium

75

A curie of natural uranium means the sum of $3.7 \times 10^{10} \mathrm{dis} / \mathrm{s}$ from uranium-238 plus $3.7 \times 10^{10} \mathrm{dis} / \mathrm{s}$ from uranium-234 plus $1.7 \times 10^{5} \mathrm{dis} / \mathrm{s}$ from uranium-235. One curie of natural uranium is equivalent to $3,000 \mathrm{~kg}$ or $6,600 \mathrm{lb}$ of natural uranium.

IIranium-238 $\quad 150$

Assumes that no other uranium isotopes are present.

Radium-226

Radium-228

Thor ium-230

Thorium-232
$5 \mathrm{pCi} / \mathrm{g}$, averaged over the first $15 \mathrm{~cm}$ of soil below the surface; $15 \mathrm{pCi} / \mathrm{g}$ when averaged over any 15-cm thick soil layer below the surface layer.

adapted from DOE (Ref. 3 ).

$\mathrm{b}_{\text {In }}$ the event of occurrence of mixtures of radionuclides, the fraction contributed by each radionuclide to its limit shall be determined, and the sum of these fractions shall not exceed 1 . If both thorium-230 and radium-226 are presently, only the one present in the highest concentration should be included in the sum. If thorium-232 and/or radium-228 are present, it may be assumed that they are in secular equilibrium and only the term for thorium-232 should be included.

CThese guidelines represent unrestricted-use residual concentrations above background averaged across any 15-rm thick layer to any depth and over any contiguous $100-\mathrm{m}^{2}$ surface area.

d Localized concentrations in excess of these limits are allowable provided that the average over $100 \mathrm{~m}^{2}$ is not exceeded. 
TABLE $4-4$

RADIONUCLIDE CONCENTRATIONS IN

SURFACE SOIL SAMPLES FROM THE WSRP SITE

$(\mathrm{pC} 1 / \mathrm{g})$

Page 1 of 3

\begin{tabular}{|c|c|c|c|c|c|}
\hline $\begin{array}{c}\text { Soil } \\
\text { Sample }\end{array}$ & Location $a, b$ & $\begin{array}{l}\text { Uranium } \\
238\end{array}$ & $\begin{array}{l}\text { Radium } \\
226\end{array}$ & $\begin{array}{c}\text { Thorium } \\
230\end{array}$ & $\begin{array}{c}\text { Thorium } \\
232\end{array}$ \\
\hline SS-1 & $20 \mathrm{C}$ & --- & $2.6 \pm 0.1$ & --- & $0.8+0.1$ \\
\hline SS-2 & $20 \mathrm{R} 10$ & --- & $0.9 \mp 0.1$ & -- & $0.2 \mp 0.1$ \\
\hline SS -3 & $20 \mathrm{~L} 10$ & -- & $2.1+0.1$ & --- & $1.0 \overline{+0} .1$ \\
\hline SS-4 & $40 \mathrm{C}$ & --- & $1.0 \mp 0.1$ & -- & $0.3+0.1$ \\
\hline s s-5 & $40 \mathrm{R} 10$ & $-\infty$ & $1.6 \mp 0.1$ & $--\infty$ & $0.6 \overline{+0} .1$ \\
\hline ss-6 & $40 \mathrm{~L} 10$ & --- & $3.7 \mp 0.1$ & -- & $1.5 \mp 0.1$ \\
\hline S S-7 & $60 \mathrm{C}$ & $---\div$ & $1.4 \mp 0.1$ & --- & $0.7 \pm 0.1$ \\
\hline SS-8 & $60 \mathrm{R} 10$ & --- & $1.8 \mp 0.1$ & --- & $1.4 \mp 0.1$ \\
\hline S S-9 & $60 \mathrm{~L} 10$ & --- & $2.6 \mp 0.1$ & --- & $1.2 \mp 0.1$ \\
\hline SS-10 & $80 \mathrm{C}$ & -- & $2.5 \mp 0.1$ & --- & $1.5 \mp 0.2$ \\
\hline SS-11 & $80 R \quad 10$ & --- & $1.7 \mp 0.1$ & --- & $1.5 \mp 0.1$ \\
\hline SS-12 & $80 \mathrm{~L} 10$ & --- & $1.1 \mp 0.1$ & -- & $1.3 \mp 0.1$ \\
\hline Ss-13 & $100 \mathrm{C}$ & --- & $1.6 \mp 0.1$ & $-\infty$ & $1: 1 \mp 0.2$ \\
\hline SS-14 & $100 \mathrm{R} 10$ & --- & $1.6 \mp 0.1$ & --- & $1.3 \mp 0.2$ \\
\hline SS -15 & $100 \mathrm{~L} 10$ & $-\infty$ & $1.4 \mp 0.1$ & --- & $0.6 \mp 0.1$ \\
\hline ss-16 & $120 \mathrm{C}$ & --- & $3.2 \mp 0.1$ & -- & $1.4 \mp 0.1$ \\
\hline Ss -17 & $120 \mathrm{R} 10$ & --- & $1.4 \mp 0.1$ & $\cdots$ & $1.0 \overline{+0} .1$ \\
\hline SS-18 & $120 \mathrm{~L} 10$ & -- & $3.2 \mp 0.1$ & --- & $1.3 \mp 0.1$ \\
\hline SS -19 & $140 \mathrm{C}$ & -- & $2.8 \mp 0.1$ & $--\infty$ & $1.8 \pm 0.2$ \\
\hline SS -20 & $140 \mathrm{R} 10$ & -- & $2.5 \mp 0.1$ & --- & $2.0 \pm 0.2$ \\
\hline$S S-21$ & 140 L 10 & --- & $2.9 \mp 0.1$ & $--\infty$ & $1.3 \pm 0.1$ \\
\hline SS-22 & $1.60 \mathrm{C}$ & -- & $2.0 \mp 0.1$ & --- & $1.6 \pm 0.1$ \\
\hline SS-23 & 160 R 10 & $--\cdots$ & $1.1 \mp 0.1$ & $-\infty$ & $1.6 \pm 0.2$ \\
\hline SS-24 & $160 \mathrm{~L} 10$ & $-\infty$ & $1.9 \mp 0.1$ & -- & $0.7 \pm 0.1$ \\
\hline SS -25 & $180 \mathrm{C}$ & -- & $3.0 \pm 0.1$ & --- & $1.5 \mp 0.1$ \\
\hline SS-26 & $180 \mathrm{R} 10$ & -- & $1.6 \mp 0.1$ & -- & $1.4 \mp 0.1$ \\
\hline SS-27 & $200 \mathrm{C}$ & $--m$ & $3.7 \mp 0.1$ & $=-\longrightarrow$ & $\mathrm{P} \overline{\mathrm{N}} \mathrm{P}$ \\
\hline SS-28 & 200 R 10 & -- & $1.2 \mp 0.1$ & -- & $1.2+0.1$ \\
\hline SS-29 & $200 \mathrm{~L} 10$ & --- & $1.2 \mp 0.1$ & -- & $0.4 \mp 0.1$ \\
\hline SS-30 & $\therefore \quad 220 \mathrm{C}$ & --- & $2.3 \mp 0.1$ & ---- & $1.1 \mp 0.1$ \\
\hline ss-31 & $220 \mathrm{R} 10$ & --- & $1.2 \mp 0.1$ & ---- & $1.3 \mp 0.1$ \\
\hline ss-32 & 220 L 10 & -- & $1.8 \mp 0.1$ & --- & $0.6 \mp 0.2$ \\
\hline ss-33 & $240 \mathrm{C}$ & --- & $1.4 \pm 0.1$ & -- & $1.3 \overline{+0} 0.1$ \\
\hline SS-34 & $240 \mathrm{R} 10$ & -- & $1.9 \mp 0.1$ & --- & $1.5 \mp 0.1$ \\
\hline SS-35 & $240 \mathrm{~L} 10$ & -- & $0.7 \mp 0.1$ & -- & $P \overline{N P}$ \\
\hline$S S-36 c$ & $26 \cap 0$ & -- & $1,3 \mp n, 1$ & $\rightarrow--$ & $1,2 \pm n, 1$ \\
\hline $\mathrm{SS}-37^{\mathrm{C}}$ & $260 \times 10$ & -- & $0.9 \mp 0.1$ & -- & $1.2 \mp 0.2$ \\
\hline $\mathrm{SS}-38^{\mathrm{C}}$ & 260 L 10 & -- & $1.0 \pm 0.1$ & --- & $0.4 \mp 0.1$ \\
\hline SS-39 & $280 \mathrm{C}$ & ---- & $1.8 \mp 0.1$ & ---- & $1.6 \mp 0.2$ \\
\hline S S-40 & $280 \times 10$ & --- & $1.6 \overrightarrow{\mp 0} .1$ & --- & $1.7 \overline{ \pm 0} .2$ \\
\hline SS-41 & $280 \mathrm{~L} 10$ & $-\infty$ & $1.4 \mp 0.1$ & $--\infty$ & $0.8 \mp 0.1$ \\
\hline ss -42 & $300 \mathrm{C}$ & --- & $2.2 \mp 0.1$ & $-\infty$ & $0.7 \mp 0.1$ \\
\hline
\end{tabular}


TABLE 4-4

(continued)

Page 2 of 3

\begin{tabular}{|c|c|c|c|c|c|}
\hline $\begin{array}{c}\text { Soil } \\
\text { Sample }\end{array}$ & Location & $\begin{array}{l}\text { Uranium } \\
238\end{array}$ & $\begin{array}{l}\text { Radium } \\
226\end{array}$ & $\begin{array}{l}\text { Thorium } \\
230\end{array}$ & $\begin{array}{l}\text { Thorium } \\
232\end{array}$ \\
\hline$s s-43$ & $300 \mathrm{R} 10$ & -- & $1.5+0.1$ & --- & $1.3+0.1$ \\
\hline s S-44 & 300 L 10 & -- & $1.3 \overline{+0} .1$ & --- & $0.3 \mp 0.1$ \\
\hline ss -45 & $320 \mathrm{C}$ & $-\infty$ & $0.9+0.1$ & --- & $1.7 \mp 0.2$ \\
\hline Ss -46 & $320 \times 10$ & -- & $1.2+0.1$ & --- & $1.4+0.1$ \\
\hline SS -47 & 320 L 10 & -- & $1.4+0.1$ & -- & $0.8+0.1$ \\
\hline SS-48 & $340 \mathrm{C}$ & - & $1.4+0.1$ & $---\infty$ & $1.5+0.2$ \\
\hline Ss -49 & $340 \mathrm{R} 10$ & -- & $1.2 \mp 0.1$ & --- & $1.3+0.1$ \\
\hline ss -50 & 340 L 10 & -- & $1.5+0.1$ & --- & $1.4+0.2$ \\
\hline SS-51 & $360 \mathrm{C}$ & - & $1.5+0.1$ & --- & $1.2 \mp 0.2$ \\
\hline ss -52 & $360 \mathrm{R} \quad 10$ & --- & $1.3+0.1$ & --- & $1.7+0.2$ \\
\hline SS -53 & 360 工 10 & $=-\infty$ & $1.8+0.1$ & -- & $1.3+0.2$ \\
\hline Ss -54 & $380 \mathrm{C}$ & -- & $0.9+0.1$ & --- & $1.5+0.1$ \\
\hline ss -55 & $380 \mathrm{R} 10$ & $-\infty$ & $1.2+0.1$ & -- & $0.7+0.1$ \\
\hline Ss -56 & 380 L 10 & - & $1.3 \mp 0.1$ & --- & $1.4+0.2$ \\
\hline ss -57 & $400 \mathrm{C}$ & -- & $1.1+0.1$ & -- & $0.4+0.1$ \\
\hline SS- 58 & $400 \times 10$ & - & $2.0 \mp 0.1$ & $\ldots$ & $1.6+0.1$ \\
\hline ss -59 & $400 \mathrm{~L} 10$ & -- & $1.5+0.1$ & -- & $1.6+0.1$ \\
\hline SS -60 & N98,045 W51,000 & $919.8+22.4$ & $213.8+3.3$ & $370+40$ & $454.9+4.2$ \\
\hline Ss-61 & N98,115 W50,860 & $23530+79.9$ & $2.7 \pm 1.4$ & -- & $12.0+1.4$ \\
\hline ss -62 & N98,115 W50,910 & $6337+49.7$ & $15.1+1.5$ & --- & $6.5+1.1$ \\
\hline$s s-63$ & N98,210 W50,950 & $7375+44.4$ & $17.7 \overline{+1} .4$ & $70+7.0$ & $2.4+0.9$ \\
\hline SS -64 & N98,235 W51,005 & $11730+59.2$ & $6.8+1.2$ & -- & $0.4+0.5^{\mathrm{d}}$ \\
\hline SS -65 & N98,245 W50,995 & $4893+39.2$ & $261.9+3.9$ & --- & $2.2+1.6$ \\
\hline$S s-65^{e}$ & N98,245 W50,995 & $676+17.6$ & $8.3+0.7$ & --- & $6.7+0.7$ \\
\hline ss-66 & N98,250 W51,150 & $34090 \overline{+97.3}$ & 1.92 .1 & $4.2+0.6$ & $\mathrm{P} \overline{\mathrm{NP}}$ \\
\hline SS-67 & $\mathrm{N} 98,300 \quad \mathrm{~W} 50,900$ & $6.6 \overline{+0} .7$ & $1.6 \overline{+0} .1$ & --二 & -- \\
\hline SS-68 & N98,500 W51,000 & $16.0 \overline{+1.2}$ & $3.7 \mp 0.2$ & $--\infty$ & $-\infty$ \\
\hline SS-69 & N9 $8,500 \quad$ W51,100 & $117.2 \overline{+8.1}$ & $2.5+0.5$ & -- & $1.1+0.6$ \\
\hline S S-70 & N9 $8,500 \quad W 51,300$ & $218.4+13.1$ & $3.1 \overline{+0} .6$ & $4.3+0.2$ & $1.3 \overline{+} 0.5$ \\
\hline S S-71 & N98,600 W51,000 & $8.3+4.3$ & $2.6+0.4$ & $-=$ & $2.7+0.4$ \\
\hline ss -72 & N98,600 W51,200 & $6.1+1.1$ & $1.4+0.3$ & -- & $1.5 \mp 0.4$ \\
\hline ss -73 & N98,600 W51,400 & $2.7+1.8$ & $1.6+0.4$ & - & $2.0 \mp 0.4$ \\
\hline Ss-74 & N98,600 W51,600 & $7.4+3.2$ & $2.0+0.6$ & -- & $1.3+0.4$ \\
\hline SS -75 & N98,600 W51,700 & $48.5+8.3$ & $2.2+0.4$ & $2.3+0.2$ & $2.2+0.3$ \\
\hline Ss-76 & N98,700 W50,700 & $11.0 \overline{+0} 0.6$ & $1.2 \overline{+} 0.1$ & $-=$ & $-\overline{-}$ \\
\hline $38-77$ & N98,700 W51,000 & $79.8+6.9$ & $1.5 \mp 0.4$ & $3.6+0.3$ & $2.1+0.4$ \\
\hline ss -78 & N98,700 W51,200 & $2.8+2.3$ & $2.2 \mp 0.3$ & $-=$ & $1.8 \overline{+0} .3$ \\
\hline ss -79 & N98,700 W51,300 & $2.5+2.0$ & $2.0 \mp 0.3$ & -- & $1.2+0.2$ \\
\hline SS -80 & N98,700 W51,500 & $9.5+3.5$ & $2.0+0.4$ & $--\infty$ & $2.1+0.3$ \\
\hline SS -81 & N98,700 W51,600 & $3.4+2.9$ & $2.0+0.3$ & $-\infty$ & $2.4+0.4$ \\
\hline $\mathrm{SS}-82$ & N98,700 W51,800 & $9.5+2.8$ & $1 . \overline{9+3.0}$ & $-\infty$ & $1 . \overline{T 0} .4$ \\
\hline SS -83 & N98,800 W50,600 & $19.5+0.3$ & $3.4+0.1$ & --- & $=$ \\
\hline s s-84 & N98,900 W50,900 & $2.0+0.2$ & $1.2+0.1$ & $-\infty$ & $-\infty-$ \\
\hline SS -85 & N99,000 W50,600 & $20.4+0.3$ & $2.3+0.0$ & -- & -- \\
\hline ss -86 & N99,000 W51,000 & $10.1+0.4$ & $1.3+0.1$ & $--\infty$ & --- \\
\hline
\end{tabular}


TABLE 4-4

(continued)

Page 3 of 3

\begin{tabular}{|c|c|c|c|c|c|c|}
\hline $\begin{array}{c}\text { Soil } \\
\text { Sample }\end{array}$ & \multicolumn{2}{|c|}{ Location } & $\begin{array}{l}\text { Uranium } \\
238\end{array}$ & $\begin{array}{l}\text { Radium } \\
226\end{array}$ & $\begin{array}{c}\text { Thorium } \\
230\end{array}$ & $\begin{array}{c}\text { Th orium } \\
232\end{array}$ \\
\hline ss -87 & $\mathrm{~N} 99,000$ & W51, 100 & $51.2+5.1$ & $19.0+1.2$ & ---- & $1.1+0.5$ \\
\hline SS-88 & N99,100 & $\mathrm{W} 50,900$ & $6.1 \overline{+1} .0$ & $2.0 \overline{+0} .1$ & --- & - \\
\hline SS-89 & $\mathrm{N} 99,100$ & W51, 300 & $12.2 \overline{+} 3.9$ & $2.3 \overline{+} 0.4$ & --- & $2.0+0.6$ \\
\hline SS-90 & N99, 100 & W51, 500 & $36.2 \mp 4.4$ & $0.2 \overline{+0} .4$ & --- & $1.2 \mp 0.7$ \\
\hline S S-91 & $\mathrm{N} 99,200$ & W50, 600 & $13.2 \mp 0.2$ & $1.5 \mp 0.0$ & --- & $-\overline{-}$ \\
\hline ss-92 & N99,200 & W50, 800 & $12.5 \overline{+1} .2$ & $3.9 \mp 0.2$ & --- & --- \\
\hline S S -93 & $\mathrm{~N} 99,200$ & W51,000 & $8.3 \mp 0.8$ & $1.2 \mp 0.1$ & $-\infty$ & --- \\
\hline Ss-94 & N99, 300 & W50,700 & $21.2 \overline{+1} .2$ & $1.8 \overline{+0} .1$ & -- & -- \\
\hline ss -95 & N99, 300 & W50,900 & $7.2 \mp 0.6$ & $1.7 \mp 0.1$ & ---- & ---- \\
\hline SS-96 & N99,300 & $W 51,500$ & $9.9 \mp 4.2$ & $3.0 \mp 0.4$ & --- & $1.9+0.4$ \\
\hline S S-97 & N99, 400 & W50,600 & $28.2 \mp 1.2$ & $1.4 \overline{+0} 0.1$ & ---- & $--=$ \\
\hline SS-98 & $\mathrm{N} 99,400$ & W50,800 & $16.1 \overline{+0} .9$ & $1.0 \overline{+0} .1$ & --- & --- \\
\hline s s-99 & $\mathrm{N} 99,400$ & W51,000 & $10.7 \mp 3.4$ & $2.6 \mp 0.6$ & ---- & $1.8+0.5$ \\
\hline SS-100 & N99, 500 & W50, 700 & $15.4 \overline{+1} .0$ & $1.1+0.1$ & $-\infty$ & $=$ \\
\hline SS-101 & N99,500 & W50,900 & $5.0+0.1$ & $1.1 \mp 0.1$ & --- & $\cdots$ \\
\hline SS-102 & N99, 500 & W51, 500 & $3.2 \mp 4.3$ & $1.2 \mp 0.4$ & -- & $1.6+0.5$ \\
\hline$s s-103$ & $\mathrm{~N} 99,500$ & W5 2,200 & $7.9 \overline{9} 5.3$ & $2.3+0.5$ & $-\infty$ & $3.6+0.6$ \\
\hline SS-104 & $\mathrm{N} 99,600$ & W50,600 & $66.0 \mp 1.1$ & $1.6 \mp 0.1$ & -- & -- \\
\hline$S S-105$ & $\mathrm{~N} 99,600$ & W50,800 & $20.6 \mp 1.0$ & $1.6 \mp 0.1$ & ---- & ---- \\
\hline SS-106 & N99,600 & W51,000 & $14.3 \overline{+2} .3$ & $1.3 \overline{+0} .3$ & $--\infty$ & $1.5+0.3$ \\
\hline SS -107 & $\mathrm{~N} 99,800$ & W51,000 & $12.9+1.9$ & $17.8 \mp 0.9$ & $11.0+1.0$ & $1.1 \mp 0.4$ \\
\hline SS-108 & N99,800 & W52, 200 & $6.8 \overline{+2} .3$ & $2.3 \mp 0.3$ & $2.1 \overline{+} 0.1$ & $2.9 \mp 0.3$ \\
\hline SS-109 & N99,900 & W51, 100 & $2.5 \overline{+3} .3$ & $8.0 \mp 0.7$ & $9.8 \mp 0.4$ & $2.5 \overline{+0} .5$ \\
\hline SS -110 & N99,900 & W51, 300 & $4.5 \overline{+2} .6$ & $2.5 \mp 0.3$ & $3.8 \mp 0.2$ & $1.7 \mp 0.3$ \\
\hline SS-111 & N99,900 & W51, 500 & $12.2 \overline{+1} .8$ & $2.4 \overline{+0} .3$ & $7.1 \mp 0.3$ & $1.4 \overline{+0} .5$ \\
\hline SS-112 & N99,900 & W52, 200 & $8.5 \overline{+3} .6$ & $2.6 \mp 0.4$ & $3.1 \mp 0.2$ & $1.8 \overline{+0.4}$ \\
\hline SS-113 & $\mathrm{N} 100,000$ & W51,400 & 161.979 .6 & $2.2 \mp 0.5$ & $7.8 \bar{\mp} \cap .5$ & $2.7 \mp 0.5$ \\
\hline$S S-114$ & $\mathrm{~N} 100,000$ & W51, 600 & $24.5 \overline{+3} .5$ & $2.0 \mp 0.6$ & $3.8^{-}$ & $\therefore n$ In 4 \\
\hline SS-115 & $\mathrm{N} 100,000$ & W51,800 & $3.6 \mp 5.1$ & $2.0 \overline{+0} .4$ & 3.6 & \\
\hline SS-116 & $\mathrm{N} 100,000$ & W5 2,000 & $5.4 \overline{+2} .7$ & $2.1 \mp 0.4$ & $1.0+0.1$ & \\
\hline SS-117 & $\mathrm{N} 100,000$ & W5 2,100 & $33.5 \mp 4.5$ & $2.0+0.3$ & $2.1+0.1$ & \\
\hline SS-118 & $\mathrm{N} 100,100$ & W5 2,000 & $21.4 \overline{+} 4.2$ & $6.0+0.6$ & $5.1 \overline{+0} .4$ & +0.5 \\
\hline
\end{tabular}

a Sampling locations are shown in Figure 4-4.

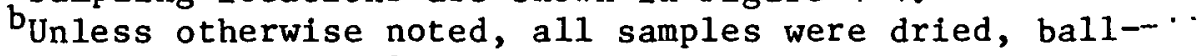

SS-1 through SS-59 were taken along the road startin cuinted. end of the site. The intersection of the fence and road is point 0 . Measurements were taken in $6.1-\mathrm{m}(20-\mathrm{ft})$ intervals on the road centerline (C), $3 \mathrm{~m}(10 \mathrm{ft})$ to the right (R 10) and $3 \mathrm{~m}(10 \mathrm{ft})$ to the left (L 10$)$. SS-60 through SS-118 were taken on the AEC grid.

Sample taken from 5 -cm $(2-i n$.$) depth$

dinitial count of wet sample

e Resample

PNP Peak not present (not detectable) 
TABLE $4-5$

BACKGROLIND RADIATION LEJELS AND NUCLIDE CONCENTRATIONS IN SURFACE SCIL SAMPLES IN THE STATE OF MISSOURI

\begin{tabular}{|c|c|c|c|c|c|}
\hline \multirow{2}{*}{$\begin{array}{l}\text { Sample } \\
\text { Designation }\end{array}$} & \multirow{2}{*}{ Description of Sample Location } & \multirow{2}{*}{$\begin{array}{c}\text { Average External } \\
\text { Gamma Exposure } \\
\text { Rate }(\mathrm{uR} / \mathrm{h})^{\mathrm{a}}\end{array}$} & \multicolumn{3}{|c|}{$\begin{array}{l}\text { Nuclide Concentration in } \\
\text { Surface Soil ( } \mathrm{pC} 1 / \mathrm{g})^{b}\end{array}$} \\
\hline & & & Radium-226 & Thorium-232 & Uranfum-238 \\
\hline MO-1 & $\begin{array}{l}\text { Approx. } 45 \mathrm{~km} E \text { of Kansas City, Missour1. } \\
\text { In pastuze fleld on } S \text { side of } \mathrm{I}-\mathrm{i} 0\end{array}$ & 6.0 & $1.4 \pm 0.04$ & $1.3 \pm 0.10$ & 1.7 \\
\hline MO-2 & $\begin{array}{l}\text { Approx. } 140 \mathrm{~km} \text { E of Kansas City, Missourl, } \\
\text { at intersection of } \mathrm{I}-70 \text { and exit } \mathrm{J} \text {, SE corner }\end{array}$ & 10.0 & $1.3 \pm 0.06$ & $1.2 \pm 0.10$ & 1.3 \\
\hline MO-3 & $\begin{array}{l}\text { Rest stop on S side of } \mathrm{I}-70, \sim 16 \mathrm{~km} \mathrm{E} \text { of } \\
\text { Williamsburg, Missour }\end{array}$ & 6.7 & $1.1 \pm 0.06$ & $1.0 \pm 0.08$ & 1.2 \\
\hline MO-4 & $\begin{array}{l}\text { SE corner of intersection of Hwy } 175 \text { and } 1-70 \\
\text { in O'Falion, Missouri }\end{array}$ & 7.5 & $1.3 \pm 0.108$ & $1.1 \pm 0.12$ & 1.1 \\
\hline Mo-5 & $\begin{array}{l}\text { Approx. } 34 \mathrm{~km} N \text {,f Missouri-Arkarsas border, } \\
\text { on E side of } \mathrm{I}-55 \text {, m1le marker } 21\end{array}$ & 8.1 & $1.2 \pm 0.04$ & $1.2 \pm 0.06$ & 1.3 \\
\hline MO-6 & $\begin{array}{l}\text { E side of } I-55, \sim 14 \mathrm{~km} N \text { of intersection } \\
\text { with Hwy Alt. } 61 \text {, at mile marker } 76\end{array}$ & 5.4 & $0.31 \pm 0.04$ & $0.32 \pm 0.04$ & 0.33 \\
\hline MO-7 & $\begin{array}{l}\text { E side of } I-55, \sim 1.6 \mathrm{~km} S \text { of Appleton ex:t } \\
E \text { of Friedheim, Hissourl }\end{array}$ & 7.6 & $1.1 \pm 0.06$ & $1.1 \pm 0.06$ & 1.1 \\
\hline MO-8 & Exit 0 off 1-55, near Bloomsdale, Missour1 & 6.8 & $0.83 \pm 0.04$ & $0.76 \pm 0.06$ & 0.81 \\
\hline MO-9 & $\begin{array}{l}\text { E side of I-55, } 0.4 \mathrm{~km} \mathrm{~S} \text { of Hwy } 141 \text { inter- } \\
\text { section, Maxvilie, Missouri }\end{array}$ & 5.1 & $1.1 \pm 0.06$ & $1.1 \pm 0.06$ & 1.1 \\
\hline MO-10 & $\begin{array}{l}\text { W side of Hwy } 36 ?, \sim 0.3 \mathrm{~km} S \text { of intersection } \\
\text { with Hwy } 67, \mathrm{~N} \text { of } \mathrm{St} \text {. Louls, Missouri }\end{array}$ & 4.6 & $1.0 \pm 0 .=0$ & $0.95 \pm 0.14$ & 0.76 \\
\hline
\end{tabular}

aExposure Fate determined from 3 to 4 measurements al each location using a "Phil" tube.

bstandard deviation of rad1un -226 and thorlum-232 mezsurements are given as the $2 \sigma$ va urantum- 238 measurements are $\leq 5 \%(2 \sigma)$.

Source: Oak Ridge National Laboratory (Ref. 4). 


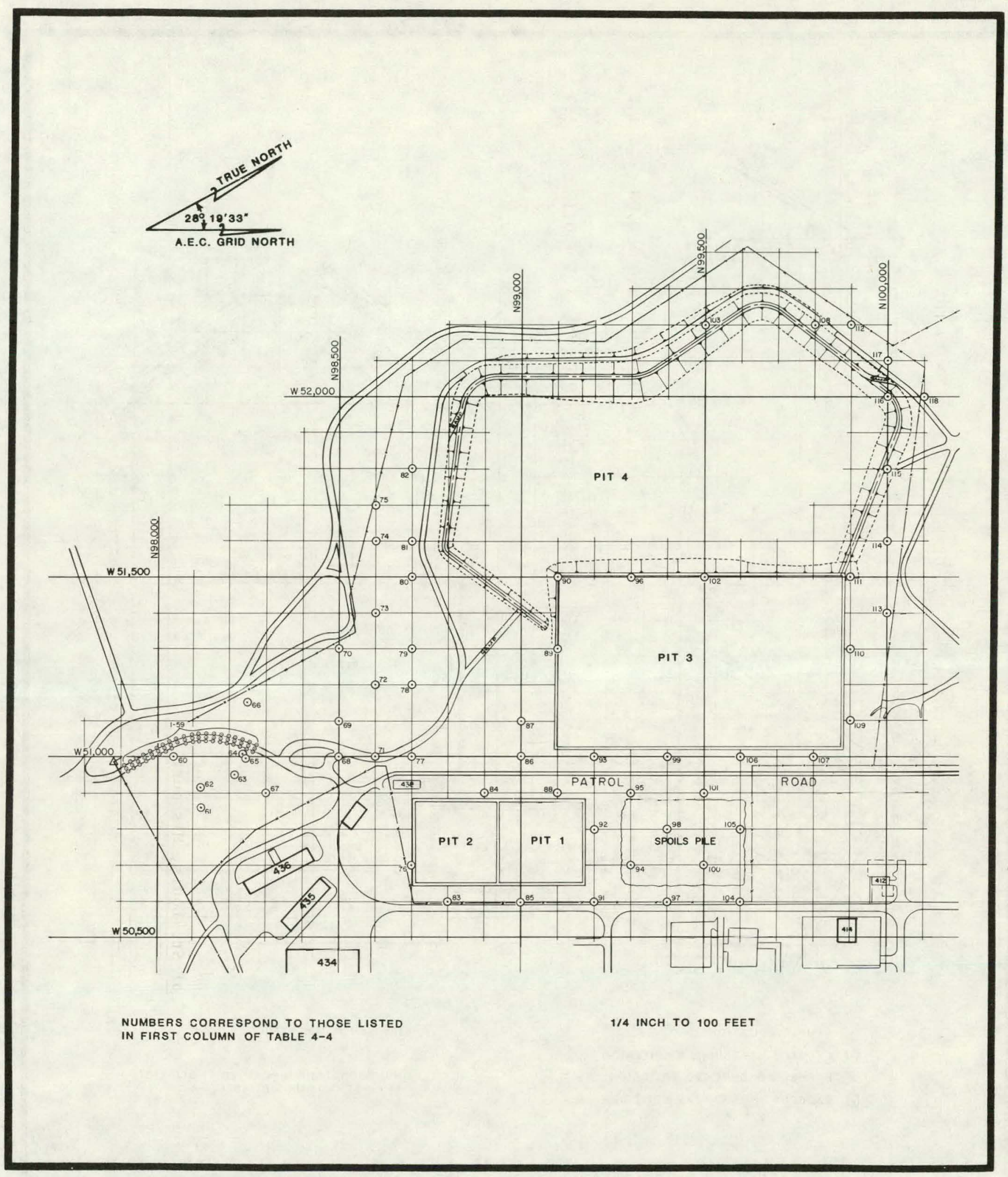

FIGURE 4-4 LOCATION OF SURFACE SOIL SAMPLES AT THE WSRP SITE 


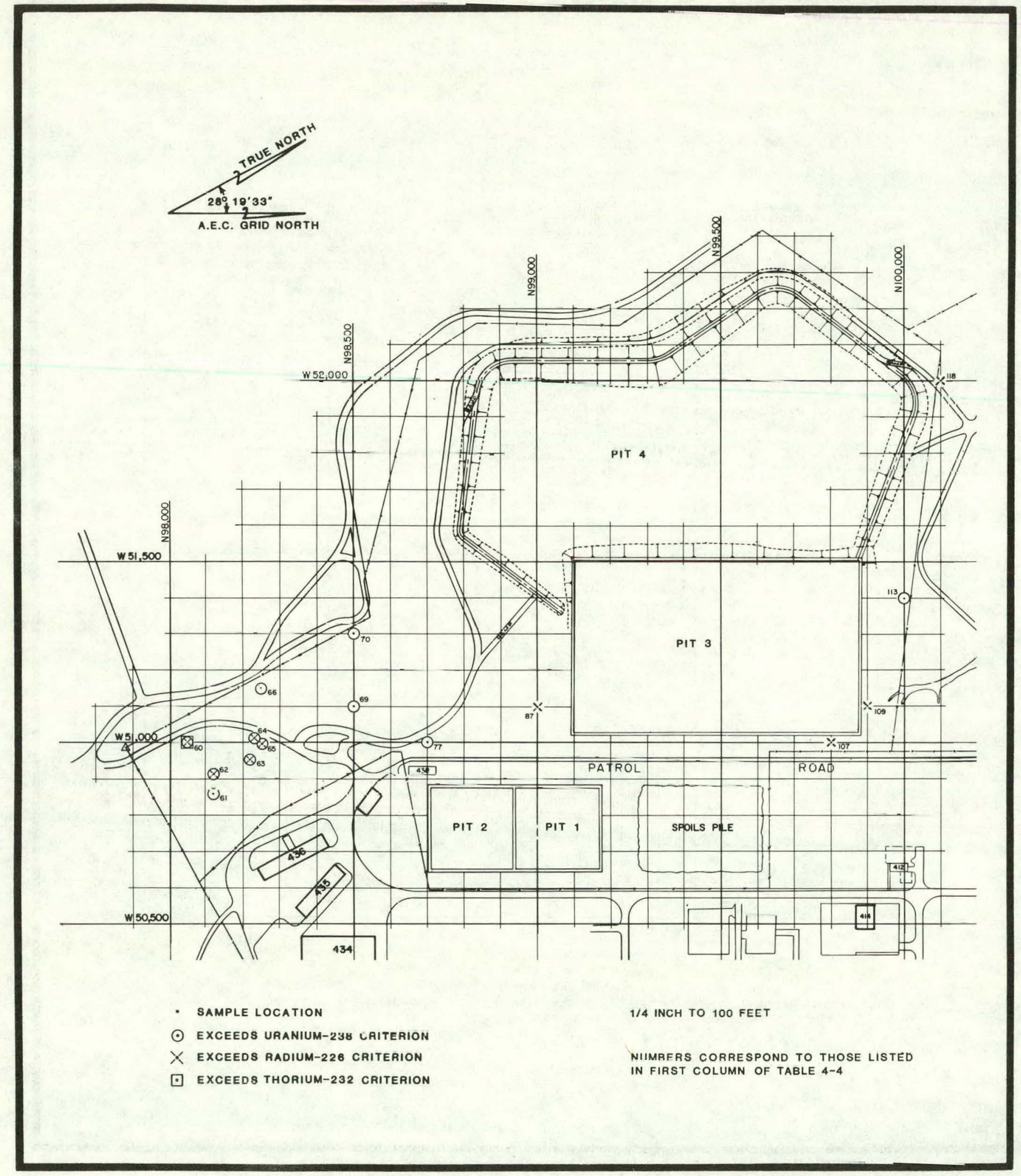

FIGURE 4-5 LOCATION OF SURFACE SOIL SAMPLES EXCEEDING URANIUM-238, RADIUM-226, AND THORIUM-232 GUIDELINES AT THE WSRP SITE 
None of the samples obtained from the side walls of the trenches exceeded guidelines for uranium-238, radium-226, and thorium-232. Table 4-6 presents sample analysis from the trench samples and Figure 4-6 indicates the locations of those samples.

Analysis of the sludge samples from the raffinate pits is presented in Table 4-7. Thorium-230 is the greatest contributor to the radioactivity of the samples. The isotopic distribution is in agreement with that expected in residues from the processing of uranium and thorium concentrates. 
TABLE 4-6

RADIONUCLIDE CONCENTRATIONS IN SIDEWALL

TRENCH SAMPLES FROM THE WSRP SITE

$(\mathrm{pCi} / \mathrm{g})$

Page 1 of 2

\begin{tabular}{lllccc}
\hline Number & Location $^{\mathrm{a}}$ & $\begin{array}{l}\text { Depth } \\
(\mathrm{ft})\end{array}$ & $\begin{array}{c}\text { Uranium } \\
238\end{array}$ & $\begin{array}{c}\text { Radium } \\
226\end{array}$ & $\begin{array}{c}\text { Thorium } \\
232^{b}\end{array}$ \\
\hline
\end{tabular}

TR-1 N98,350, W50,910 0-1

$1-2$

$2-3$

$1.5 \pm 0.3$
$1.0 \pm 0.5$

$0.9 \pm 0.21 .4 \pm 0.4$

$1.7 \pm 3.8^{\mathrm{b}}$

$1.1 \mp 0.1 \quad 1.2 \mp 0.3$

TR-2 N98,420, W51,230 $\begin{array}{ll}0-1 \\ 1-2\end{array}$

$20.0 \pm 1.1$
$4.4 \pm 0.0$
$1.0 \mathrm{~b}$

$1.4 \pm 0.2$

$0.9 \pm 0.4$

$2-3$

$1.1+0.1 \quad 1.3+0.5$

$0-1$

$1-2$

$2-3$

$2.7 \pm 0.4$
$<1.0 \mathrm{~b}^{ \pm}$
$<1.0^{\mathrm{b}}$

$1.0 \mp 0.0$

$0.8 \pm 0.2$

$\mathrm{TR}-3$

N98,570, W51, 520

$0-1$

$1-2$

$2-3$

$1.6+0.3$

TR-4 N98,700, W52,030

$0.4 \pm 0.8$

$1.1 \pm 0.7$

$1.0 \pm 0.1$

$<0.5$

$0.3+0.5 \quad 1.0 \pm 0.2 \quad 0.9+0.4$

TR-5 N98, 840, W5 2, 075 $\quad 0-1$
$1-2$
$2-3$

$\begin{array}{ll}\text { TR-5 N98, 840, W5 2, 075 } & 0-1 \\ & 1-2 \\ & 2-3\end{array}$

$\begin{array}{ll}\text { TR-5 N98, 840, W5 2, 075 } & 0-1 \\ & 1-2 \\ & 2-3\end{array}$

$0.7 \mp 0.5$

$1.6 \pm 0.5$

$1.1 \pm 0.1$
$0.8+0.2$

$0.9+0.2$

$1.3 \mp 0.2$

$0.6 \mp 0.4$

TR-6 N98,955, W51,080 0-1

$1-2$

$2-3$

$1.3 \pm 1.6^{b}$

$1.0+0.1$

$0.8 \mp 0.3$

TR-7 N99,455, W52,260 $\begin{aligned} & 0-1 \\ & 1-2\end{aligned}$

$0.6 \pm 1.0$

$1.3 \pm 0.2$

$1.1+0.2$

$0.7 \mp 0.3$

$0.7 \pm 0.3$
$0.9 \pm 0.4$

$2-3$

$1.5 \mp 0.4$

$1.2 \mp 0.1 \quad 1.2 \mp 0.4$

$1.1 \pm 0.1 \quad 0.9 \pm 0.2$

TR-B N99,625, W52,390 0-1

1-2

$1.0^{\mathrm{b}}$

\section{$0.7+0.7$}

$1.0 \pm 0.1 \quad 1.2 \pm 0.4$

$0.6 \pm 0.4$

$1.2 \mp 0.1$

$<0.5$

$1.0 \mp 0.1$

$0.8 \pm 0.4$

$2-3$

$<1.0^{b}$

$<1.0^{b}$

$0.9 \pm 0.5$

$0.8 \pm 0.1$

$0.9 \pm 0.2$

$0.3+0.1$

$1.6 \mp 0.1$

$0.1 \mp 0.9$

TR-9 N99,950, W51,070 0-1

$1-2$

$3.9 \pm 0.6$
$1.3 \pm 0.6$

$1.2 \pm 0.2$

$1.1 \pm 0.3$

$2-3$

TR-10 N99,990, W51,530 0-1

$1-2$

$2-3$

$1.0 \pm 0.2$

$0.8+0.3$

$1.0 \pm 0.3$

$1.1 \pm 0.3$

$$
<1.0^{\mathrm{b}}
$$

$1.1 \pm 0.2 \quad 0.8 \pm 0.2$
$1.0+0.1<0.5$

$1.6 \pm 0.2 \quad 1.3 \pm 0.4$

$$
\begin{aligned}
& 4.5 \pm 0.5 \\
& <1.0 \mathrm{~b}= \\
& 0.6 \pm 0.4
\end{aligned}
$$

$1.0 \pm 0$.
$0.8 \pm 0.4$

$1.0 \pm 0.1$

$1.1 \pm 0.3$
$0.1 \pm 0.3$

$0.5 \pm 0.3$ 
TABLE 4-6

(continued)

Page 2 of 2

\begin{tabular}{|c|c|c|c|c|c|}
\hline Number & Location & $\begin{array}{l}\text { Depth } \\
(\mathrm{ft})\end{array}$ & $\begin{array}{l}\text { Uranium } \\
\quad 238\end{array}$ & $\begin{array}{l}\text { Radium } \\
226\end{array}$ & $\begin{array}{l}\text { Thorium } \\
232^{b}\end{array}$ \\
\hline$T R-11$ & N99,990, 51,540 & $\begin{array}{l}\text { Sewer Pipe } \\
12-14 "\end{array}$ & $6.3 \pm 0.8$ & $1.2 \pm 0.1$ & $<0.5$ \\
\hline TR -12 & $\mathrm{~N} 100,080, W 52,040$ & $\begin{array}{l}0-1 \\
1-2 \\
2-3\end{array}$ & $\begin{array}{l}1.8 \pm 0.4 \\
2.4 \pm 1.5^{b} \\
1.0 b^{b}\end{array}$ & $\begin{array}{l}1.0 \pm 0.1 \\
1.2 \pm 0.1 \\
1.3 \pm 0.2\end{array}$ & $\begin{array}{l}0.8 \pm 0.2 \\
1.4 \pm 0.3 \\
0.8 \pm 0.4\end{array}$ \\
\hline
\end{tabular}

asampling locations are shown on Figure 4-6.

breliminary analysis 


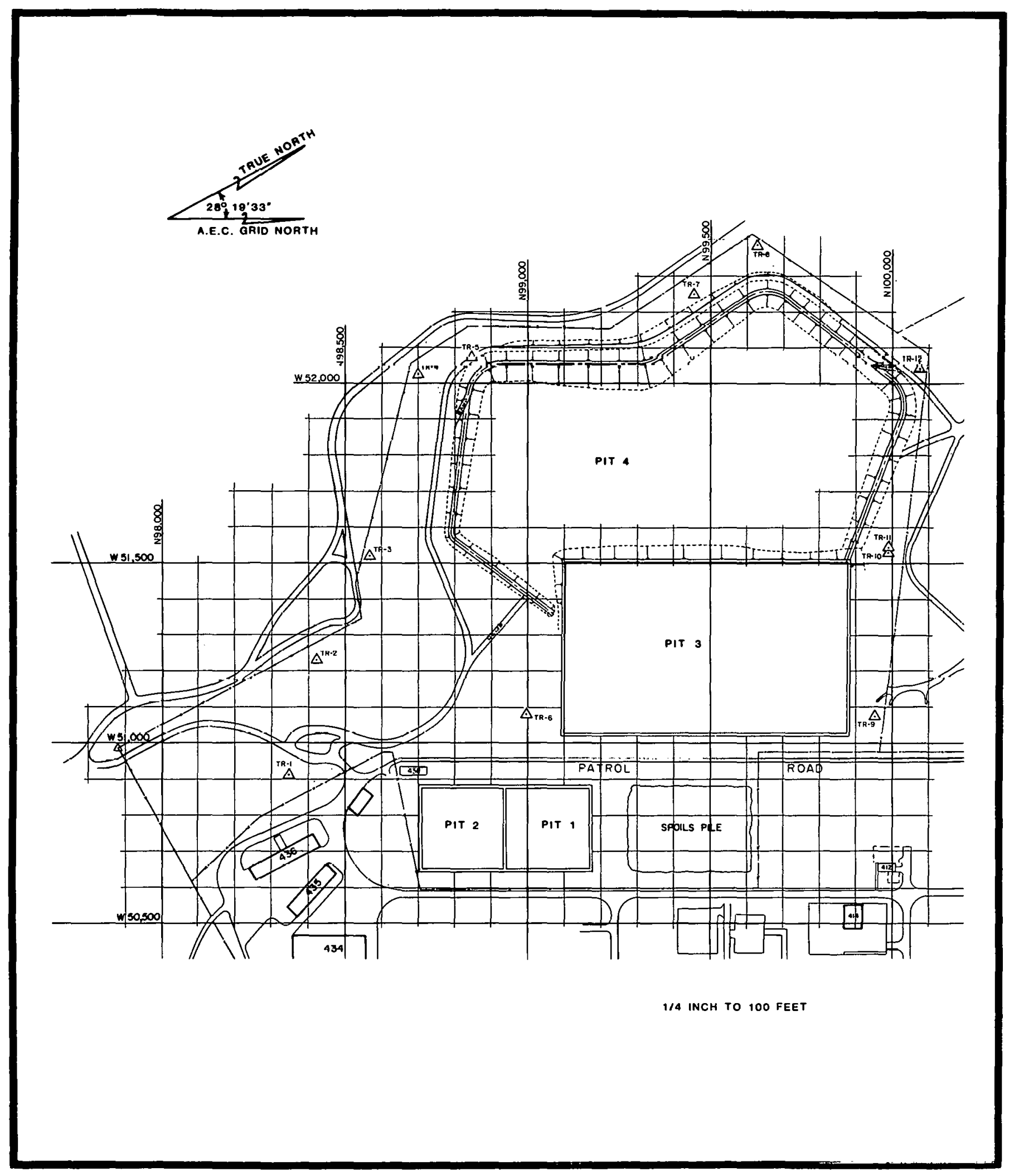

FIGURE 4-6 LOCATION OF TRENCH SOIL SAMPLES AT THE WSRP SITE 
TABLE $4-7$

RADIONUCLIDE CONTENTS OF THE

WELDON SPRING RAFFINATE PITS

$(\mathrm{pCi} / \mathrm{g}$ dry $)$

\begin{tabular}{lcccc}
\hline Radionuclide & Pit 1 & Pit 2 & Pit 3 & Pit 4 \\
\hline Radium-226 & $430 \pm 130$ & $440 \pm 130$ & $460 \pm 130$ & $11 \pm 3$ \\
Radium-228 & $850 \pm 85$ & $200 \pm 20$ & $100 \pm 10$ & $60 \pm 10$ \\
Thorium-232 & $100 \pm 20$ & $120 \pm 20$ & $120 \pm 20$ & $120 \pm 20$ \\
Thorium-230 & $24000 \pm 1000$ & $24000 \pm 1000$ & $14000 \pm 1000$ & $1600 \pm 100$ \\
Uranium-238 & $710 \pm 70$ & $470 \pm 40$ & $520 \pm 50$ & $620 \pm 60$ \\
Uranium-234 & $810 \pm 80$ & $560 \pm 50$ & $570 \pm 50$ & $610 \pm 60$ \\
Uranium-235 & $40 \pm 5$ & $30 \pm 4$ & $30 \pm 4$ & $30 \pm 4$
\end{tabular}




\subsection{SUMMARY AND SIGNIFICANCE OF FINDINGS}

A comprehensive radiological survey of the WSRP site was conducted in 1982 and 1983 by BNI/EIC. The survey included surface radiation scans, measurements of direct radiation levels, and analyses for radionuclide concentrations in soil samples, both surface and subsurface.

The results of the survey indicate areas of elevated direct radiation levels and surface soil contamination exceeding guidelines. Areas of elevated uranium-238 concentrations are primarily in the southern area of the site. These locations are visually identifiable. They consist of bare patches (alkaline in appearance) or scrap material. The contamination appears to be confined to the surface or near-surface layers, as confirmed by subsurface sampling, gamma logs of boreholes, and resampling from contaminated areas. Elevated radium-226 concentrations were found at several locations on the downhill (northeast) slope of Raffinate Pit 3. This area is in the path of the old slurry lines from the WSCP.

Although there are areas of contamination exceeding guidelines, most of the site is below guidelines for uranium-238, radium-226, thorium-230, and thorium-232. Sludge samples from the Raffinate Pits indicate a mixture of radionuclides differing from natural equilibrium. Uranium concentrates typically may contain up to five percent thorium (Ref. 5). Processing of these concentrates would then produce a thorium-enriched residue accounting for the elevated concentrations of thorium-230 in the sludge.

The average exposure rate on site was $23 \mu \mathrm{R} / \mathrm{h}$. This is below the $60 \mathrm{\mu R} / \mathrm{h}$ standard for unrestricted exposure of the general public. This site is a restricted area, which further limits the exposure of individuals. 


\section{REFERENCES}

1. NLO, Inc. Environmental Monitoring Program for the DOE Weldon Spring Missouri Site, NCLO-009EV (SPECIAL), Cincinnati, OH, 1981.

2. U.S. Code of Federal Regulations. 10 CFR 20.105, "Permissible Levels of Radiation in Unrestricted Areas," Washington; D.C., January 1983.

3. U.S. Department of Energy - "Interim Planning Guidelines and Criteria for Residual Radioactive Materials at Formerly Utilized Sites Remedial Action Program (FUSRAP) and Remote Surplus Facilities Management Program (SFMP) Sites" (Draft), July 11, 1984.

4. Oak Ridge National Laboratory. State Background Radiation Levels: Results of Measurements Taken During 1975-1979, ORNL/TM-7343, Oak Ridge, TN, 1981.

5. U.S. Nuclear Regulatory Commission. Office of Nuclear Material Safety and Safeguards. Generic Environmental Impact Statement on Uranium Milling, (draft), NUREG-0511, Volume 2, Washington, DC, April 1979. 
